CrossMark $<$ click for updates

Cite this: Org. Biomol. Chem., 2016, 14, 2731

Received 20th December 2015 Accepted 29th January 2016

DOI: 10.1039/c5ob02617b

www.rsc.org/obc

\section{Chemoselective and stereoselective lithium carbenoid mediated cyclopropanation of acyclic allylic alcohols $\dagger$}

\author{
M. J. Durán-Peña, $t^{a}$ M. E. Flores-Giubi, ț J. M. Botubol-Ares, ${ }^{a}$ L. M. Harwood, ${ }^{b}$ \\ I. G. Collado, ${ }^{a}$ A. J. Macías-Sánchez ${ }^{\star a}$ and R. Hernández-Galán*a
}

\section{Introduction}

Cyclopropane-containing molecules are found in many natural and unnatural compounds exhibiting relevant biological activities $^{1}$ as enzymatic inhibitors, ${ }^{2}$ plant growth regulators and fruit senescence regulators, insecticides, antifungals, herbicides, tumour promoters and compounds with effects on cell growth division. ${ }^{3}$ Cyclopropane ring containing compounds have also been found useful as synthetic intermediates in the preparation of cyclic ${ }^{4,5}$ or acyclic compounds. ${ }^{6}$

In general terms, cyclopropane rings can be mainly prepared either by cyclization of a three membered ring unit, or by the reaction between a two carbon and a one carbon unit. Several methods have been described such as Michael-initiated ring closure, ${ }^{7}$ reaction of carbenes originated from diazoalkanes $^{8}$ and catalysed by transition metals, ${ }^{9}$ cycloisomerizarions catalysed by transition metals ${ }^{10}$ the Kulinkovich reaction ${ }^{11}$ and carbene or carbenoid ${ }^{12}$ addition to olefins. Many of these methods involve stereoselective ${ }^{13}$ and enantioselective ${ }^{14}$ reac-

\footnotetext{
${ }^{a}$ Departamento de Química Orgánica, Facultad de Ciencias, Campus Universitario Puerto Real s/n, Torre sur, $4^{\circ}$ planta; Universidad de Cádiz, 11510 Puerto Real, Cádiz, Spain.E-mail: rosario.hernandez@uca.es, antoniojose.macias@uca.es ${ }^{b}$ Department of Chemistry, University of Reading, Whiteknights, Reading RG6 6AD, $U K$

$\dagger$ Electronic supplementary information (ESI) available: Copies of ${ }^{1} \mathrm{H}$ and ${ }^{13} \mathrm{C}$ NMR spectra for all new compounds appearing in the schemes (compounds $3 \mathbf{b}$, 6-13, 14a-c, 15b-c, 16b-c, 18a-c, and 19a-c), copies of selected 2D NMR experiments for compounds $\mathbf{9}, \mathbf{1 0}$, copies of ${ }^{1} \mathrm{H}$ NMR spectra for known compounds prepared by the general procedure of cyclopropanation (compounds 4 and 5), together with the copies of NOESY 2D NMR experiments for compounds $\mathbf{6}, \mathbf{8}$ and 11 and copies of NOESY 1D NMR experiments for compounds 7, 9, 12, 14b, 18b and 19b. See DOI: 10.1039/c5ob02617b

$\$$ Both authors contributed equally to the work.
}

tions and the use of organocatalysts has also been described. ${ }^{14 c, 15}$

An example of a metal-carbenoid reagent successfully applied in the chemo- and stereoselective ${ }^{16}$ cyclopropanation of alkenes is the Simmons-Smith reagent, ${ }^{17}$ where a number of modifications of the original zinc-copper couple based Simmons-Smith methodology have recently been reported. ${ }^{18}$ This reaction has been extended to the preparation of 1,2,3substituted halocyclopropanes involving the diastereoselective ${ }^{19}$ and enantioselective ${ }^{19 c, 20}$ transfer of carbenoids.

Lithium carbenoids ${ }^{21}$ are recognised as organometallic compounds bearing both a lithium atom and an electronegative element $\mathrm{X}\left(\mathrm{X}=\right.$ halogen, $\left.\mathrm{OR}, \mathrm{NR}_{2}\right)$ on the same carbon. Reactivity of lithium carbenoids is influenced by both their structural features and interplay of aggregation and solvation effects, as shown by the behavior of $\alpha$-lithiated styrene oxide and related compounds under different experimental conditions. ${ }^{22}$

In general terms, $\alpha$-heteroatom-substituted alkyl lithium compounds are generated in solution under inert conditions and at low temperatures and used without further purification. While monohalo-substituted alkanes are not acidic enough to allow for the preparation of these compounds, ${ }^{23}$ further halogen substitution on the same carbon increases the acidity and, for instance, gem-dichloroalkanes are precursors of $\alpha$-dichloro alkyl lithium compounds. ${ }^{24}$ Therefore, the reaction of these compounds with alkenes would lead to the preparation of chlorocyclopropanes.

Furthermore, heavier halogens undergo the Wittig-Gilman halogen-lithium exchange reaction more readily and, accordingly, gem-dibromoalkanes can undergo the Wittig-Gilman halogen-lithium exchange reaction and give rise to $\alpha$-bromo alkyl lithium compounds. ${ }^{23,25}$ 


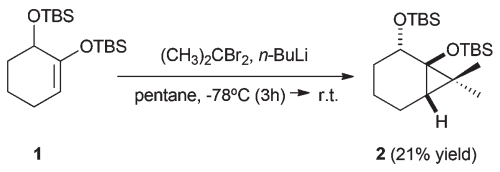

Scheme 1 gem-Dimethylcyclopropanation of 1.

Interestingly, while the chemoselective and stereoselective incorporation of a methylene group in the Simmons-Smith cyclopropanation has been extensively investigated, ${ }^{13 a, 26}$ selective introduction of a more elaborated moiety via intermolecular reaction has been less explored.

In this context, construction of a gem-dimethylcyclopropane unit is of interest, since it is a structural feature present in many natural products ${ }^{3,27}$ and their derivatives; for instance pyrethrins and their unnatural derivatives, pyrethroids. $^{28}$ Several methods have been developed for the gem-dimethylmethylene cyclopropanation of alkenes. ${ }^{29-31}$ Among them zinc and lithium dimethylmethylenecarbenoids have been described as efficient cyclopropanation reagents. ${ }^{30,31}$

In a previous study, our group studied the diastereoselective preparation of 7,7-dimethylbicyclo[4.1.0]heptan-1,2-diol via cyclopropanation of 1,2-di-tert-butyldimethylsilyloxycyclohexene 1 with a lithium carbenoid generated from 2,2-dibromopropane at $-78{ }^{\circ} \mathrm{C}$ with a low yield (21\%) (Scheme 1). ${ }^{32}$ Facial diastereoselectivity of this reaction seems to be determined by the secondary alcohol stereochemistry, suggesting some sort of coordination between the substrate and the intermediate lithium carbenoid, in a similar fashion to the situation observed between zinc carbenoids and allylic alcohols in the Simmons-Smith reaction. ${ }^{33}$

Geraniol has been used as a model in the study of the chemoselectivity in the reaction of cyclopropanation of alkenes with several reagent systems. Three membered rings can be formed either at the double bond proximal to the alcohol or at the distal one. Reagents based on $\mathrm{Zn},{ }^{34,35} \mathrm{Sm},{ }^{36,37} \mathrm{Mg}^{38}$ and $\mathrm{Ti}^{39}$ lead to cyclopropanation of the proximal double bond. Nevertheless, aluminium based reagents lead to cyclopropane formation at the distal double bond. ${ }^{40,41}$ There are reports on the reactivity of lithium carbenoids with allylic hydroxyl groups or related systems, but to our knowledge, there are no studies on the chemoselectivity of lithium carbenoids. ${ }^{42-44}$

Herein, we evaluate the chemoselectivity of the cyclopropanation of geraniol mediated by a series of lithium carbenoids, and we focus our attention on the chemoselective incorporation of a gem-dimethylcyclopropane unit into several allylic alcohols.

\section{Results and discussion}

A long-standing debate on the mechanistic nature of carbenoid-mediated cyclopropanations can be found in the literature where two alternative mechanistic pathways have been proposed; namely methylene-transfer and carbometalation. ${ }^{45-49}$

On experimental grounds, a methylene transfer mechanism should give compounds where the configurational integrity of the double bond is retained in the resulting cyclopropanation product, which might not be the case for a two-step carbometalation mechanism. ${ }^{50}$

Some studies suggest that this mechanistic dichotomy is metal-dependent. Therefore, for zinc carbenoids, experimental $^{45}$ and theoretical studies ${ }^{48,49}$ suggest that the methylene transfer mechanism is prevalent, as also seems to be the case for aluminium-mediated cyclopropanations. ${ }^{40,51}$ Regarding lithium-carbenoid mediated olefin cyclopropanation, arguments for both mechanistic proposals can be found. ${ }^{46,50-52}$

In recent years, several theoretical studies have addressed on this topic where the aggregation state of the lithium carbenoid seems to play a key role. For instance, $n$-BuLi is a hexamer in the solid state $\left(n-\mathrm{Bu}_{6} \mathrm{Li}_{6}\right)$, and this aggregation state is mainly retained in non-polar media; while in more polar media, such as $\mathrm{Et}_{2} \mathrm{O}$, dimers and tetramers predominate. ${ }^{53}$ A common conclusion from these studies is the dominance of the methylene transfer mechanism over carbometalation when polymeric species for the halomethyl lithium carbenoids are dominant, a likely situation in nonpolar solvents. ${ }^{54-56}$

Coordination with Lewis bases, either attached to the olefin, such as with allylic alcohols, or not, as is the case in coordination with polar solvents such as $\mathrm{Et}_{2} \mathrm{O}$ or $\mathrm{THF}$ is another factor needed to be taken into account to understand these reactions. This situation has been examined for lithium carbenoids on the internal cyclopropanation of a chiral carbenoid, ${ }^{46}$ where theoretical studies support a methylene transfer mechanism, ${ }^{54}$ as seems to be the case when coordination by polar solvents such as THF are taken into account in addition to the aggregation state of the halomethyl lithium carbenoid. ${ }^{56}$

All these studies suggest a parallel behaviour of halomethyl lithium carbenoids to the one described by the SimmonsSmith reaction; although no experimental data are available for the chemoselectivity and stereoselectivity of the reaction of substituted halomethyl lithium carbenoids, thus justifying the study presented here.

Prior to studying the chemoselectivity of geraniol with a set of lithium carbenoids, the conditions reported for the cyclopropanation of substrate 1 with 2,2-dibromopropane (Scheme 1) were re-evaluated with the aim of improving the yield and/or the conversion of the gem-dimethylcyclopropanation. We examined the effect of the reagent and substrate ratios, the solvent and the metalating agent. The use of pentane as the solvent was crucial for the success of this reaction since the reaction did not take place when THF or diethyl ether was employed. Furthermore, the reaction did not occur when $t$-BuLi was used in place of $n$-BuLi. The best yield was obtained when the reaction was carried out at $-78{ }^{\circ} \mathrm{C}$ using 4 equiv. of 2,2-dibromopropane and 8 equiv. of $n$-BuLi, achieving an optimal $50 \%$ of yield, an improvement on 
previously described conditions (21\% yield) (see ESI, Table S1, entry $4 \dagger$ ).

In previous work, we have reported that the titaniummediated cyclopropanation of geraniol by $\mathrm{CH}_{2} \mathrm{I}_{2}$ may proceed without previous protection of the hydroxyl group. ${ }^{39}$ Therefore, we expected that the presence of an unprotected hydroxyl group would be compatible with the use of $n$-BuLi in pentane in combination with a methylene source for alkene cyclopropanation. Consequently, in order to gain further insight into the chemoselectivity of the reaction, we explored the effect of different lithium carbenoids, using unprotected geraniol as a model substrate (Table 1).

First, the treatment of geraniol (3a) with either dibromomethane or diiodomethane and $n$-BuLi at $-78{ }^{\circ} \mathrm{C}$ (Table 1 , entries 1 and 2) led to the formation of the cyclopropanation product 4 by methylene addition on the double bond closest to the hydroxyl group in moderate yield. Additionally, reaction with dibromomethane led to the double cyclopropanation product 5. This behaviour is similar to that described for the

Table 1 Cyclopropanation of geraniol with a set of lithium carbenoids

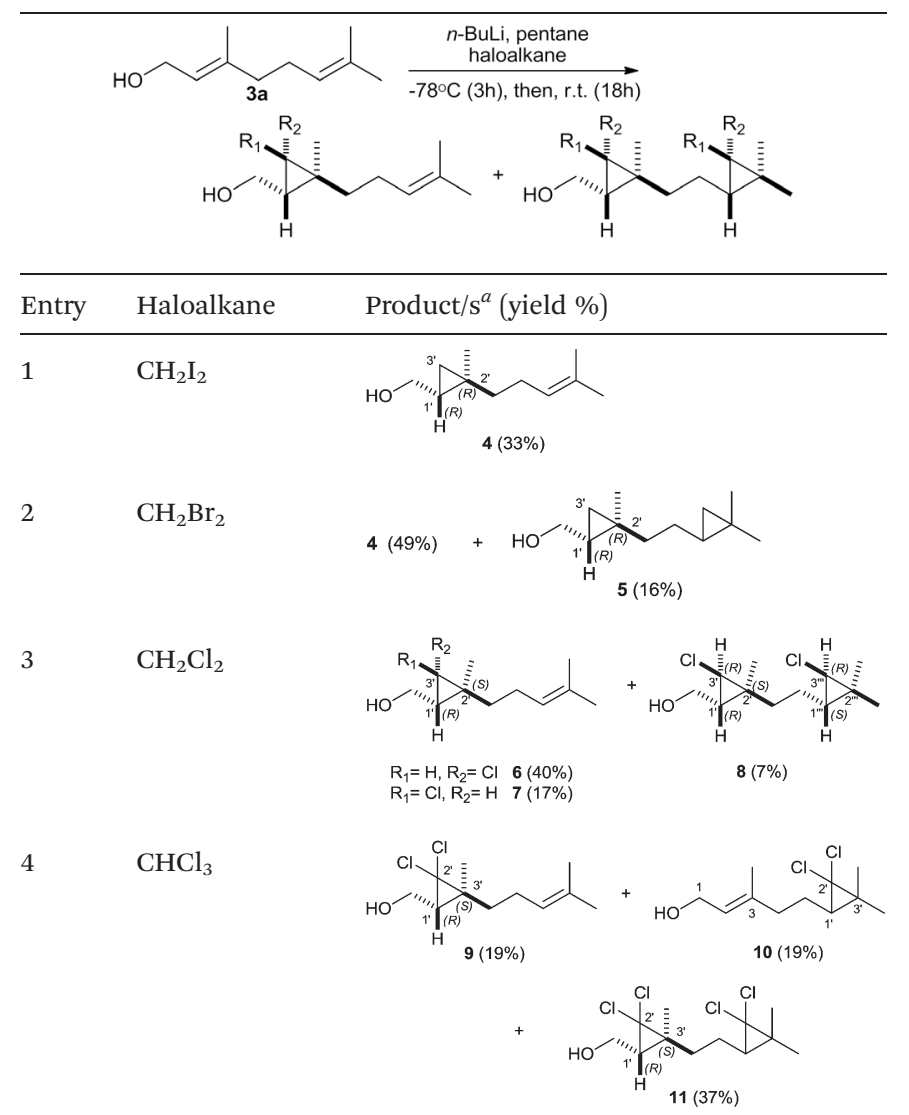

$5 \quad \mathrm{CH}_{3} \mathrm{CH}_{2} \mathrm{CHCl}_{2}$

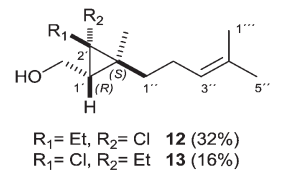

${ }^{a}$ Yields were evaluated by GC.
Simmons-Smith reaction. ${ }^{34,35}$ Spectroscopic and spectrometric data for compounds $\mathbf{4}$ and $\mathbf{5}$ are in agreement with those described in the literature. ${ }^{57,58}$

On the other hand, reaction between geraniol and the lithium dichlorocarbenoid generated from $\mathrm{CH}_{2} \mathrm{Cl}_{2}$ and $n$-BuLi led to the formation of chlorocyclopropanols 6 (40\%), 7 (17\%) and the double monochlorocyclopropanation product $\mathbf{8}$, in low yield (7\%) (Table 1, entry 3). Compounds 6 and 7 displayed similar signal patterns in their ${ }^{13} \mathrm{C}$ NMR spectra, presenting 2 quaternary carbons, 3 methine, 3 methylene and 3 methyl groups. Then the main reaction product, compound $\mathbf{6}$, showed a HRMS molecular ion at $\mathrm{m} / z=202.1120$, consistent with the molecular formula $\mathrm{C}_{11} \mathrm{H}_{19} \mathrm{OCl}$, while compound 7 showed in its HRMS $\left(\mathrm{APGC}^{+}\right.$) an ion at $m / z=185.1111$, consistent with the molecular formula $\mathrm{C}_{11} \mathrm{H}_{18} \mathrm{Cl}$, which would correspond to a loss of water from a protonated molecular ion of the formula $\mathrm{C}_{11} \mathrm{H}_{20} \mathrm{OCl}$. Compound 6 presented signals at $\delta_{\mathrm{C}} 131.5$ and $124.3 \mathrm{ppm}$ in its ${ }^{13} \mathrm{C} \mathrm{NMR}$ spectrum and a signal at $\delta_{\mathrm{H}}$ $5.01 \mathrm{ppm}$ in its ${ }^{1} \mathrm{H}$ NMR spectrum while compound 7 presented signals at $\delta_{\mathrm{C}} 131.7$ and $124.9 \mathrm{ppm}$ in its ${ }^{13} \mathrm{C}$ NMR spectrum and a signal at $\delta_{\mathrm{H}} 5.18 \mathrm{ppm}$ in its ${ }^{1} \mathrm{H}$ NMR spectrum, which reveals a remaining double bond on each compound.

On the other hand, both compounds presented spin systems in their ${ }^{1} \mathrm{H}$ NMR spectra corresponding to the protons attached to $\mathrm{C}-1, \mathrm{C}-1^{\prime}$ and $\mathrm{C}-3^{\prime}, \delta_{\mathrm{H}} 3.59(\mathrm{CHHOH}), \delta_{\mathrm{H}} 3.53$ $(\mathrm{CH}-\mathrm{HOH}), 2.70\left(\mathrm{CH}_{-} 3^{\prime}\right)$ and $\left.0.77\left(\mathrm{CH}^{-1}\right)^{\prime}\right)$ ppm for compound 6 and $\delta_{\mathrm{H}} 3.29(\mathrm{C} \underline{\mathrm{HOH}}), 2.99(\mathrm{CH} \underline{\mathrm{HOH}}), 2.44\left(\mathrm{CH}^{-} 3^{\prime}\right)$ and $\delta_{\mathrm{H}}$ $0.96\left(\mathrm{CH}^{-1}\right) \mathrm{ppm}$ for compound 7, which are consistent with the formation of a chlorocyclopropane ring at the allylic double bond.

NOESY 2D correlations between the protons of the hydroxymethylene group with the proton of the methine group at $\mathrm{C}-\mathrm{I}^{\prime}$, on one hand, and with the protons of the methyl group attached at C-2' on the other, and between the proton of the methine group at C-3' and the proton of the methine group at $\mathrm{C}-1$ ', on one hand, and with the protons of the methylene group at C-1-" on the other, allowed us to determine the stereochemistry for compound 6 as $1^{\prime} R^{*}, 2^{\prime} S^{*}, 3^{\prime} S^{*}$ (Fig. 1). Correspondingly, a NOESY 1D correlation between the proton of the methine group at $\mathrm{C}-3^{\prime}$ and the protons of the methyl group attached to $\mathrm{C}-2^{\prime}$ was consistent with the proposed stereochemistry for compound 7 as $1^{\prime} R^{*}, 2^{\prime} S^{*}, 3^{\prime} R^{*}$ (Fig. 2).

Compound 8 displayed a different signal pattern in its ${ }^{13} \mathrm{C}$ NMR spectrum, presenting 2 quaternary carbons, 4 methyne, 3 methylene and 3 methyl groups. This compound showed ion peaks in its HRMS $\left(\mathrm{APGC}^{+}\right)$at $m / z=215.1203$ and 179.1431

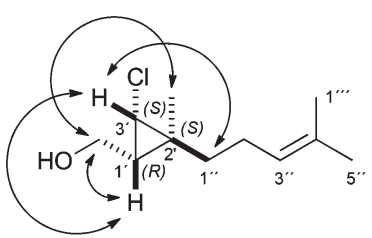

Fig. 1 Selected NOESY 2D correlations for compound 6 . 


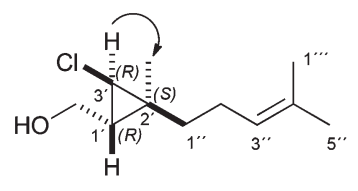

Fig. 2 Selected NOESY 1D correlations for compound 7.

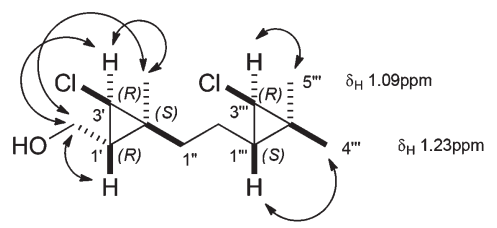

Fig. 3 Selected NOESY 2D correlations for compound 8

consistent, respectively, with formulas $\mathrm{C}_{12} \mathrm{H}_{20} \mathrm{OCl}$ and $\mathrm{C}_{12} \mathrm{H}_{19} \mathrm{O}$, that correspond to the loss of one and two molecules of $\mathrm{HCl}$ from a protonated molecular ion of the formula $\mathrm{C}_{12} \mathrm{H}_{21} \mathrm{OCl}_{2}$. Compound 8 lacked double bond resonance signals in its NMR spectrum, but presented a spin system in its ${ }^{1} \mathrm{H}-\mathrm{NMR}$ spectrum corresponding to the protons attached to $\mathrm{C}-1, \mathrm{C}-1^{\prime}$ and $\mathrm{C}-3^{\prime}\left(\delta_{\mathrm{H}} 3.78(\mathrm{CHHOH}), 3.56(\mathrm{CH}-\underline{H}), 2.79\right.$ $\left(\mathrm{CH}_{-} \mathbf{3}^{\prime}\right)$ and 1.18 ( $\left.\left.\underline{\mathrm{H}}^{-} \mathbf{1}^{\prime}\right) \mathrm{ppm}\right)$, in a similar fashion to that observed for compound 7. This established that a chlorocyclopropanation took place at the allylic double bond. In addition, a doublet at $\delta_{\mathrm{H}} 2.57$ (H-3"') ppm confirmed further chlorocyclopropanation of the distal double bond of geraniol. NOESY 2D correlations between $\mathrm{CHHOH}$ and $\mathrm{CHHOH}$ with $\mathrm{CH}_{-1} \mathbf{1}^{\prime}$, $\mathrm{CH}-3^{\prime}$ and $\mathrm{CH}_{3}$ on $\mathrm{C}-2$ ', on one hand, and among $\mathrm{CH}-3^{\prime}$ with $\mathrm{CH}_{3}$ on $\mathrm{C}-2^{\prime}, \mathrm{CH}^{-1}{ }^{\prime \prime \prime}$ with the protons of the methyl group at C-4"' $\left(\delta_{\mathrm{H}} 1.23 \mathrm{ppm}\right)$ and $\mathrm{CH}^{-} 3^{\prime \prime \prime}$ with the protons of the methyl group at C-5"' ( $\left.\delta_{\mathrm{H}} 1.09 \mathrm{ppm}\right)$ allowed us to determine stereochemistry for compound 8 as $1^{\prime} R^{*}, 2^{\prime} S^{*}, 3^{\prime} R^{*}, 1^{\prime \prime \prime} S^{*}, 3^{\prime \prime \prime} R^{*}$ (Fig. 3).

The observed stereochemistries of the monochlorocyclopropanes 6 and 7, and the chemoselectivity showed that the preferential formation of the chlorocyclopropane rings on the proximal olefin of geraniol are consistent for a syn addition reaction of the lithium chlorocarbenoid and thus a mechanism involving methylene transfer (Table 1, entry 3).

On the other hand, the treatment of geraniol with $\mathrm{CHCl}_{3}$ and $n$-BuLi gave a $1: 1: 2$ mixture of the dichlorocyclopropanes proximal (9), distal $(\mathbf{1 0})^{59}$ and double cyclopropyl derivative $(\mathbf{1 1})^{60}$ (Table 1, entry 4). The dichlorocyclopropanation compound 9 showed ions at its $\mathrm{HRMS}\left(\mathrm{APGC}^{+}\right)$analysis at $m / z=$ 219.0712, 201.1046 and 183.0947, consistent, respectively with formulas $\mathrm{C}_{11} \mathrm{H}_{17} \mathrm{Cl}_{2}, \mathrm{C}_{11} \mathrm{H}_{18} \mathrm{OCl}$ and $\mathrm{C}_{11} \mathrm{H}_{16} \mathrm{Cl}$, that correspond to the loss of one molecule of water, the loss of a molecule of $\mathrm{HCl}$ and the loss of a molecule of water and another of $\mathrm{HCl}$ from a protonated ion of molecular formula $\mathrm{C}_{11} \mathrm{H}_{19} \mathrm{OCl}_{2}$ respectively. The presence of two chlorine atoms in the compound 9 was confirmed by a quaternary carbon resonance at $\delta_{\mathrm{C}} 71.1\left(\mathrm{C}-2^{\prime}\right) \mathrm{ppm}$ in its ${ }^{13} \mathrm{C}$ NMR spectrum. Furthermore, gHMBC correlations from this latter carbon with signals at

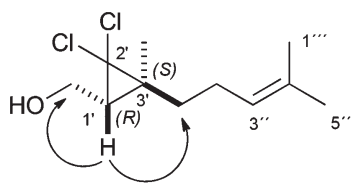

Fig. 4 Selected NOESY 1D correlations for compound 9.

$\delta_{\mathrm{H}}\left(\mathrm{C}_{6} \mathrm{D}_{6}\right) 0.96\left(\left(\mathrm{CH}_{3}\right) \mathrm{C}-3^{\prime}\right), 1.26\left(\mathrm{H}-1^{\prime}\right), 1.50\left(\mathrm{CH}_{2}-1^{\prime \prime}\right)$ and 3.31 $(\mathrm{CH}+\mathrm{HOH}) \mathrm{ppm}$ together with the NOESY 1D effects shown in Fig. $\overline{4}$ were consistent with a syn dichlorocyclopropanation at the proximal olefin.

The use of $\mathrm{CHCl}_{3}$ did not show any chemoselectivity, in contrast to the lithium carbenoid generated from $\mathrm{CH}_{2} \mathrm{Cl}_{2}$ (Table 1, entry 4). The formation of a mixture of the monocyclopropanation products $\mathbf{9}$ and $\mathbf{1 0}$ and the double cyclopropanation product $\mathbf{1 1}$ can be explained with a competition of mechanisms, both by lithium carbenoid and free carbene. A free carbene mechanism would lead to distal dichlorocyclopropanation or double dichlorocyclopropanation, as shown by Zlotin et al. in the cyclopropanation of acetylgeraniol with $\mathrm{KOH}$ and $\mathrm{CHCl}_{3}$ in benzene. ${ }^{61}$

On the other hand, when 1,1-dichloropropane was used as the cyclopropanation reagent, we only obtained the corresponding syn monochloroethylcyclopropanation products on the proximal olefin of geraniol, 12 and 13, in a $2: 1$ ratio (Table 1, entry 5). Cyclopropanation on the distal olefin or double cyclopropanation products were not observed. Both compounds showed ions at their HRMS mass spectra $\left(\mathrm{CI}^{+}\right)$at $m / z=229.1358$ and 229.1354, respectively, which correspond to a loss of molecular hydrogen from a protonated molecular ion of formula $\mathrm{C}_{13} \mathrm{H}_{24} \mathrm{OCl}$. COSY vicinal correlations between signals corresponding to $\mathrm{CH}_{2} \mathrm{OH}$ and $\mathrm{CH}_{-}-1^{\prime}$ and between $\mathrm{CH}_{-}-$ 3 " and $\mathrm{CH}_{2}-2$ " and long range correlations among $\mathrm{CH}-3$ " and $\mathrm{C}_{3}-1^{\prime \prime \prime}$ and $\mathrm{CH}_{3}-5$ " were consistent with the above mentioned cyclopropanation pattern for both compounds. For compound 12, NOESY $1 \mathrm{D}$ effects between the signal at $\delta_{\mathrm{H}} 0.59\left(\mathrm{CH}-1^{\prime}\right)$ ppm and signals at $\delta_{\mathrm{H}} 3.64\left(\mathrm{CH}_{2} \mathrm{OH}\right), 1.70\left(\mathrm{CH}_{3} \mathrm{CHHCCl}\right), 1.57$

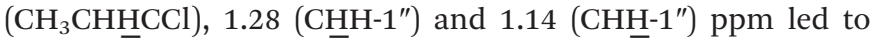
the assignment of its structure as $\left(\left(1 R^{*}, 2 S^{*}, 3 S^{*}\right)\right.$-2-chloro-2ethyl-3-methyl-3-(4-methylpent-3-en-1-yl)cyclopropyl)methanol

(Fig. 5). This, in turn, allows the assignment of the relative stereochemistry of compound 13 as $\left(1^{\prime} R^{*}, 2^{\prime} R^{*}, 3^{\prime} S^{*}\right)$.

As shown in Table 1, dichloroalkyl reagents led to syn monochlorocyclopropanation products and some level of chemoselectivity was observed. This chemoselectivity was lost when $\mathrm{CHCl}_{3}$ is employed. Chemoselectivity increased with

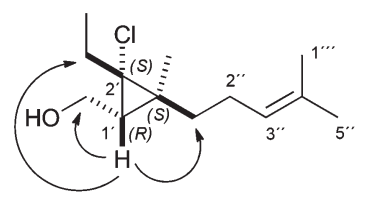

Fig. 5 Selected NOESY 1D correlations for compound 12. 
alkyl substitution as shown for cyclopropanation products using 1,1-dichloropropane as the starting material. An increased level of chemoselectivity was also observed for $\mathrm{CH}_{2} \mathrm{Br}_{2}$ and especially for $\mathrm{CH}_{2} \mathrm{I}_{2}$. Therefore, as cyclopropanation using $\mathrm{CH}_{2} \mathrm{Br}_{2}$ already led to some degree of chemoselectivity, increasing alkyl substitution on the $\alpha$-dibromoalkyl reagent should lead to an increased level of chemoselectivity.

On the other hand, the use of 2,2-dibromopropane as a lithium carbenoid precursor would prevent a carbolithiation mechanism, as the resulting open intermediate, would have to evolve through the attack of a lithium carbanion on a tertiary bromide, which would be too hindered for an $\mathrm{S}_{\mathrm{N}} 2$ process. Therefore, the reactions should proceed in a stereoselective and chemoselective manner, provided a Lewis base assisted concerted mechanism is involved. The influence of steric hindrance and protection of the hydroxyl group on the course of the reaction was also evaluated.

The reaction of geraniol (3a) and its silylated and benzyl derivatives (compounds $\mathbf{3 b}$ and $\mathbf{3 c}$ ) with 2,2-dibromopropane and $n$-BuLi in pentane led, in every single case, to a single product $(\mathbf{1 4 a}-\mathbf{c})$ in yields ranging $45-81 \%$ (Table 2 , entry 1 ). When compared with the starting material, compounds $\mathbf{1 4 a - c}$ presented the lack of an olefin signal in their ${ }^{1} \mathrm{H}$ NMR spectra together with the presence of two new singlet methyl groups. On the other hand, COSY correlations between the $\mathrm{H}-1^{\prime}$

Table 2 Cyclopropanation of geraniol and related compounds with 2,2-dibromopropane

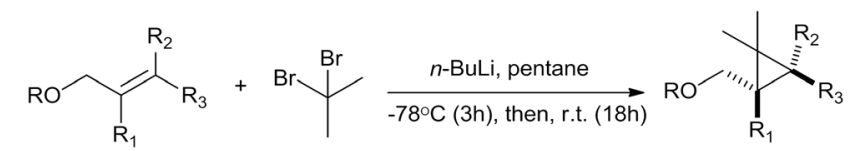

Entry Substrate $\quad$ Products $^{a}$ (yield \%)

1

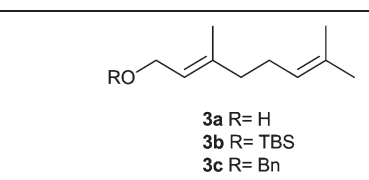

2

3

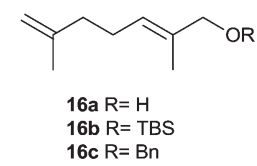

4

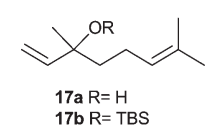

${ }^{a}$ Yields were evaluated by GC.

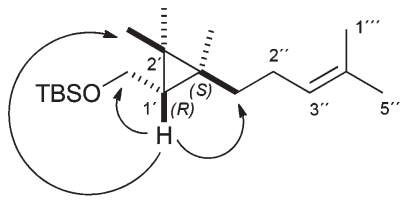

Fig. 6 Selected NOESY 1D correlations for compound 14b.

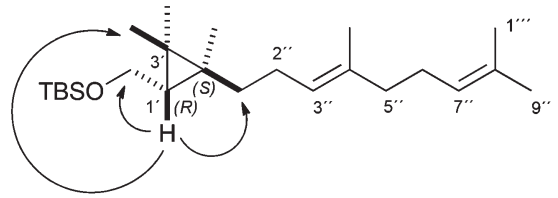

Fig. 7 Selected NOESY 1D correlations for compound 18b.

protons and each $\mathrm{CH}_{2} \mathrm{OH}$ group confirmed the cyclopropanation in the proximal olefin.

NOESY-1D effects, evaluated on the silyl derivative $\mathbf{1 4 b}$, between the signal at $\delta_{\mathrm{H}} 0.46\left(\mathrm{CH}^{\prime} 1^{\prime}\right) \mathrm{ppm}$ and signals at $\delta_{\mathrm{H}}$ $3.64(\mathrm{CHHOH}), 3.59(\mathrm{CH} \underline{\mathrm{HOH}}), 1.37\left(\mathrm{CH}_{2}-^{\prime \prime}\right)$ and $1.11\left(\left(\mathrm{CH}_{3}\right)\right.$ $\left.\left(\mathrm{CH}_{3}\right) \mathrm{C}-2^{\prime}\right)$ ppm allowed us to establish the relative stereochemistry of compound $\mathbf{1 4 b}$, and in turn of compounds 14a and $14 \mathrm{c}$, as $1^{\prime} R^{*}, 3^{\prime} S^{*}$ (Fig. 6).

Extension of this methodology to farnesol (15a), $(E)$-2,6-dimethylhepta-2,6-dien-1-ol ${ }^{62}$ (16a) and their silyl and benzyl derivatives (15b-c, $\mathbf{1 6 b}-\mathbf{c})$ led to single cyclopropanation products in every case (Table 2, entries 2 and 3). On the other hand, treatment of linalool (17) and its silyl derivative $\mathbf{1 7 b}$ under the same reaction conditions only led to the recovery of starting materials (Table 2, entry 4).

In a similar fashion to geraniol cyclopropanation products 14a-c, compounds 18a-c and 19a-c, compared with their starting materials, presented the lack of an olefin signal in their ${ }^{1} \mathrm{H}$ NMR spectra, together with the presence of two new singlet methyl groups. For compounds 18a-c, COSY correlations between each proton from the methyne group at the position C-1' and each $\mathrm{CH}_{2} \mathrm{OH}$ group, confirmed the cyclopropanation in the proximal olefin. For compounds 19a-c, COSY correlations between each proton from the methyne group at the position $\mathrm{C}-3^{\prime}$ and $\mathrm{CH}_{2}-1^{\prime \prime}$ protons confirmed the cyclopropanation in the proximal olefin.

NOESY-1D effects, evaluated on the silyl derivative $\mathbf{1 8 b}$, between the signal at $\delta_{\mathrm{H}} 0.46\left(\mathrm{CH}_{-} \mathbf{1}^{\prime}\right) \mathrm{ppm}$ and signals at $\delta_{\mathrm{H}}$ $3.64(\mathrm{C} \underline{H} \mathrm{HOH}), 3.59(\mathrm{CH} \underline{\mathrm{HOH}}), 1.24-1.42\left(\mathrm{CH}_{2}-1^{\prime \prime}\right)$ and 1.10 $\left(\left(\mathrm{CH}_{3}\right)\left(\overline{C H}_{3}\right) \mathrm{C}-3^{\prime}\right)$ ppm allowed us to establish the relative stereochemistry of compound $\mathbf{1 8 b}$, and, then in turn one of the compounds 18a and 18c, as $1^{\prime} R^{*}, 2^{\prime} S^{*}$ (Fig. 7).

NOESY-1D effects, evaluated on the silyl derivative $19 \mathbf{b}$, between the signal at $\delta_{\mathrm{H}} 0.25\left(\mathrm{CH}_{-}-3^{\prime}\right) \mathrm{ppm}$ and signals at $\delta_{\mathrm{H}}$ $3.53(\mathrm{C} \underline{H} \mathrm{HOH}), 3.40(\mathrm{CH} \underline{\mathrm{HOH}}), 2.01\left(\mathrm{C}_{2}-2^{\prime \prime}\right), 1.37\left(\mathrm{C}_{2}-1^{\prime \prime}\right)$ and $1.08\left(\left(\mathrm{CH}_{3}\right)\left(\mathrm{CH}_{3}\right) \mathrm{C}-2^{\prime}\right)$ ppm allowed us to establish the relative stereochemistry of compound $\mathbf{1 9 b}$, then in turn one of the compounds 19a and 19c, as $1^{\prime} R^{*}, 3^{\prime} S^{*}$ (Fig. 8). Therefore, stereo- 


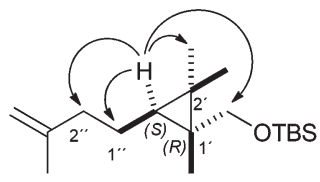

Fig. 8 Selected NOESY 1D correlations for compound 19b.

chemistry observed for compounds $14 a-c, 18 a-c$ and $19 a-c$ is consistent with a chemoselective, syn gem-dimethylcyclopropanation, on the proximal double bond on the parent compounds.

The results shown in Table 2 indicate a consistent chemoselectivity and stereoselectivity for the cyclopropanation of polyenols on the proximal double bond to the oxygen atom. On the other hand, relatively lower yields are observed for the gem-dimethylcyclopropanation of the TBS derivatives of the trisubstituted allylic alcohols $\mathbf{3 b} \mathbf{b} \mathbf{1 5} \mathbf{b}$ and $\mathbf{1 6 b}$, compared to the unprotected (compounds 3a, 15a, and 16a) or benzylated derivatives (compounds 3c, 15c, and 16c). Furthermore, compounds $\mathbf{1 7} \mathbf{a}$ and $\mathbf{1 7} \mathbf{b}$, that present a tertiary alcohol or silyl ether moiety, do not lead to cyclopropanation products. These observations are consistent with a Lewis base assisted (oxygen) concerted mechanism, where steric hindrance in the environment of the oxygen atom would hamper coordination with the gem-dimethyl lithium carbenoid that would react with the allylic double bond.

\section{Conclusions}

We have investigated the chemoselectivity of the cyclopropanation of geraniol with a series of lithium carbenoids. We found variable levels of chemoselectivity when we generated the carbenoid from dihalomethanes $\left(\mathrm{CH}_{2} \mathrm{Cl}_{2}, \mathrm{CH}_{2} \mathrm{Br}_{2}, \mathrm{CH}_{2} \mathrm{I}_{2}\right)$, obtaining mainly the cyclopropyl derivative at the proximal olefin to the hydroxyl group (Table 1, entries 1-3). However, chemoselectivity was not observed when the reaction was carried out with $\mathrm{CHCl}_{3}$ (Table 1, entry 4). On the other hand, the use of 1,1-dichloropropane and 2,2-dibromopropane led to the chemoselective cyclopropanation of the proximal olefin on the substrates examined.

Furthermore, we have obtained the chemoselective incorporation of a gem-dimethyl cyclopropane unit into several terpenols from moderate to good yields where the presence of an allylic hydroxyl group directs the course of the reaction.

These results are consistent with a directing effect from the oxygen in the functionality to the allylic position, which would be involved in a Lewis base assisted concerted cyclopropanation mechanism. Preservation of the stereochemistry of the starting double bond in the cyclopropanation process was found with all the lithium carbenoids tested, and the chemoselectivity observed is consistent with a methylene transfer mechanism that is reminiscent of that described for the Simmons-Smith reaction.

\section{Experimental}

\section{General procedures}

Unless otherwise noted, materials and reagents were obtained from commercial suppliers and were used without further purification. Dried solvents were obtained from PureSolv ${ }^{\circledR}$ equipment, tetrahydrofuran was freshly distilled from $\mathrm{Na}$ and dichloromethane was freshly distilled from $\mathrm{CaH}_{2}$. Air- and moisture-sensitive reactions were performed under an argon atmosphere. Purification by semipreparative HPLC was performed with a Hitachi/Merck L-6270 apparatus equipped with a differential refractometer detector (RI-7490). A LiChrospher® Si $60(10 \mu \mathrm{m})$ LiChroCart ${ }^{\circledR}(250 \mathrm{~mm} \times 10 \mathrm{~mm})$ column was used in isolation experiments. Silica gel (Merck) was used for column chromatography. TLC was performed on Merck Kieselgel 60 F254, $0.25 \mathrm{~mm}$ thick. Infrared spectra were recorded on a FT-IR spectrophotometer and reported as wavenumbers $\left(\mathrm{cm}^{-1}\right) \cdot{ }^{1} \mathrm{H}$ and ${ }^{13} \mathrm{C}$ NMR measurements were obtained on 400 , 500 or $600 \mathrm{MHz}$ spectrometers with $\mathrm{SiMe}_{4}$ as the internal reference. Chemical shifts were referenced to $\mathrm{CDCl}_{3}\left(\delta_{\mathrm{H}} 7.25, \delta_{\mathrm{C}}\right.$ 77.0), or $\mathrm{C}_{6} \mathrm{D}_{6}\left(\delta_{\mathrm{H}} 7.16, \delta_{\mathrm{C}} 128.1\right)$. NMR assignments were made by a combination of $1 \mathrm{D}$ and $2 \mathrm{D}$ techniques. Multiplicities are described using the following abbreviations: $\mathrm{s}=$ singlet, $\mathrm{d}=$ doublet, $\mathrm{t}=$ triplet, $\mathrm{q}=$ quartet, $\mathrm{m}=$ multiplet, and br = broad. High-Resolution Mass Spectroscopy (HRMS) was performed either with a double-focusing magnetic sector mass spectrometer in chemical ionization positive ion mode, using methane as the reactant gas, or in a QTOF mass spectrometer in positive ion ESI or APCI modes $\left(\mathrm{APGC}^{+}\right.$for samples analysed by GC chromatography).

\section{Synthesis of the substrates}

Preparation of compound 16a. This compound was obtained by the procedure described in the literature and spectroscopic data were identical to those described in the literature. $^{62}$

General procedure for the preparation of silyl ethers $3 \mathrm{~b}, \mathbf{1 5 b}$ and 16b. A solution of tert-butylchlorodimethylsilane ( $2 \mathrm{mmol})$ in dry THF $(1.5 \mathrm{~mL})$ was added to a solution of imidazole $(10.6 \mathrm{mmol})$ and the corresponding alcohol $(1.3 \mathrm{mmol})$ in dry $\mathrm{THF}(2.2 \mathrm{~mL})$ at $0{ }^{\circ} \mathrm{C}$ under an inert atmosphere. The mixture was allowed to warm to room temperature and when TLC monitoring indicated completion of the reaction $(12 \mathrm{~h})$, diethyl ether was added $(20 \mathrm{~mL})$. The organic layer was washed with brine $(3 \times 80 \mathrm{~mL})$, dried over anhydrous sodium sulfate, filtered and the solvent evaporated under reduced pressure. The crude residue was purified by silica gel column chromatography to yield quantitatively the corresponding silylated derivative $\mathbf{3 b}, \mathbf{1 5 b}$ and $\mathbf{1 6 b}$.

(E)-1-(tert-Butyldimethylsilyloxy)-3,7-dimethylocta-2,6-diene (3b). (98\% yield). Colourless oil; IR (film) $\nu_{\max } 2928,2857$, 1670, $1254 \mathrm{~cm}^{-1} ;{ }^{1} \mathrm{H}$ NMR (400 MHz, $\left.\mathrm{CDCl}_{3}\right) \delta 5.29(1 \mathrm{H}, \mathrm{m})$, $5.08(1 \mathrm{H}, \mathrm{m}), 4.18(1 \mathrm{H}, \mathrm{d}, J 6.3 \mathrm{~Hz}), 2.08(2 \mathrm{H}, \mathrm{m}), 2.00(2 \mathrm{H}, \mathrm{m})$, 1.67 (3H, d, J $1.1 \mathrm{~Hz}), 1.61$ (3H, s), $1.59(3 \mathrm{H}, \mathrm{s}), 0.88(9 \mathrm{H}, \mathrm{s})$, 0.06 (6H, s); ${ }^{13} \mathrm{C}$ NMR (100 MHz, $\left.\mathrm{CDCl}_{3}\right) \delta 136.8,131.4,124.4$, $124.1,60.3,39.5,26.4,26.0$ (3C), 25.6, 18.4, 17.6, 16.3, -5.1 
(2C); HRMS $\left(\mathrm{CI}^{+}\right)$calcd for $\mathrm{C}_{16} \mathrm{H}_{32} \mathrm{OSi}[\mathrm{M}]^{+}$268.2222, found 268.2206.

(2E,6E)-1-(tert-Butyldimethylsilyloxy)-3,7,1,1-trimethyldodeca2,6,10-triene (15b). (99\% yield). Colourless oil; IR (film) $\nu_{\max }$ 2928, 2864, 1462, 1433, 1376, 1251, 1107, 1062, 835, $771 \mathrm{~cm}^{-1}$; ${ }^{1} \mathrm{H}$ NMR (400 MHz, $\left.\mathrm{CDCl}_{3}\right) \delta 5.30(1 \mathrm{Hm}), 5.09(2 \mathrm{H}, \mathrm{m}), 4.18$ $(2 \mathrm{H}, \mathrm{d}, J 6.6 \mathrm{~Hz}), 2.12-1.95(8 \mathrm{H}, \mathrm{m}), 1.67(3 \mathrm{H}, \mathrm{s}), 1.62(3 \mathrm{H}, \mathrm{s})$, $1.59(6 \mathrm{H}, \mathrm{s}), 0.90(9 \mathrm{H}, \mathrm{s}), 0.06(6 \mathrm{H}, \mathrm{s}) ;{ }^{13} \mathrm{C}$ NMR $(100 \mathrm{MHz}$, $\left.\mathrm{CDCl}_{3}\right) \delta 136.9,135.1,131.2,124.4,124.3,124.0,60.3,39.7$, 39.6, 26.7, 26.3, 26.0 (3C), 25.7, 18.4, 17.7, 16.4, 16.0, -5.0 (2C); HRMS $\left(\mathrm{CI}^{+}\right)$calcd for $\mathrm{C}_{21} \mathrm{H}_{39} \mathrm{OSi}[\mathrm{M}-\mathrm{H}]^{+} 335.2770$, found 335.2761.

(E)-1-(tert-Butyldimethylsilyloxy)-2,6-dimethylhepta-2,6-diene (16b). (98.5\% yield). Colourless oil; IR (film) $\nu_{\max } 2956,2929$, 2857, 1650, 1462, 1253, 1110, 886, $775 \mathrm{~cm}^{-1}$; ${ }^{1} \mathrm{H}$ NMR $\left(400 \mathrm{MHz}, \mathrm{CDCl}_{3}\right) \delta 5.39(1 \mathrm{H}, \mathrm{m}), 4.70(1 \mathrm{H}, \mathrm{br} \mathrm{s}), 4.68(1 \mathrm{H}, \mathrm{br}$ $\mathrm{s}), 4.00(2 \mathrm{H}, \mathrm{s}), 2.16(2 \mathrm{H}, \mathrm{m}), 2.05(2 \mathrm{H}, \mathrm{m}), 1.72(3 \mathrm{H}, \mathrm{s}), 1.60$ $(3 \mathrm{H}, \mathrm{s}), 0.90(9 \mathrm{H}, \mathrm{s}), 0.05(6 \mathrm{H}, \mathrm{s}) ;{ }^{13} \mathrm{C}$ NMR $\left(100 \mathrm{MHz}, \mathrm{CDCl}_{3}\right)$ $\delta$ 145.7, 134.5, 124.1, 110.0, 68.6, 37.5, 26.0 (3C), 25.8, 22.4, 18.4, 13.4, -5.3 (2C); HRMS $\left(\mathrm{CI}^{+}\right)$calcd for $\mathrm{C}_{11} \mathrm{H}_{21} \mathrm{OSi}$ $\left[\mathrm{M}-\mathrm{C}\left(\mathrm{CH}_{3}\right)_{3}\right]^{+} 197.1362$, found 197.1361.

Preparation of compound $\mathbf{1 7 b}$. To a stirred solution of linalool (16a) (200 mg, $1.3 \mathrm{mmol})$ and DIPEA (0.23 mL, $1.56 \mathrm{mmol})$ in anhydrous dichloromethane $(21 \mathrm{~mL})$ was added dropwise tert-butyldimethylsilyltrifluoromethane sulfonate (TBSOTf, $0.33 \mathrm{~mL}, 1.43 \mathrm{mmol}$ ). The reaction mixture was stirred for 3 hours and then diluted with dichloromethane $(20 \mathrm{~mL})$. The solution was washed with brine and the organic layer was dried over anhydrous sodium sulfate. Filtration followed by evaporation of the solvent led to the crude product that was purified by silica gel column chromatography to yield the corresponding silyl derivative 17b (342.8 mg; 98.5\%). Spectroscopic data of the compound $\mathbf{1 7} \mathbf{b}$, were identical to those described in the literature. ${ }^{63}$

General procedure for the preparation of benzyl ethers 3c, 15c and 16c. Sodium hydride $(60 \%$ in oil, $184.8 \mathrm{mg}$, $4.62 \mathrm{mmol}$ ) was washed twice with hexane and suspended in dry dimethylformamide $(7.9 \mathrm{~mL})$. A solution of the requisite alcohol $(2.57 \mathrm{mmol})$ dissolved in dry $\mathrm{N}, \mathrm{N}$-dimethylformamide $(0.5 \mathrm{~mL})$ was added and the mixture was stirred for $10 \mathrm{~min}$. Then, a solution of benzyl chloride $(0.45 \mathrm{~mL}, 3.85 \mathrm{mmol})$ was added and the mixture was allowed to warm for $8 \mathrm{~h}$. The mixture was poured into water, the layers separated and the aqueous layer was extracted three times with diethyl ether $(3 \times$ $50 \mathrm{~mL}$ ). The combined extracts were washed with brine, dried over sodium sulfate, filtered and concentrated. The crude mixture was purified by silica gel column chromatography to yield the corresponding benzyl derivatives $3 \mathbf{c}(73 \%), \mathbf{1 5 c}(70 \%)$ and $\mathbf{1 6 c}(68 \%)$. Spectroscopic data of compound $3 \mathbf{c}$ were identical to those described in the literature. ${ }^{64}$

(2E,6E)-1-Benzyloxy-3,7,11-trimethyldodeca-2,6,10-triene (15c). (70\% yield). Yellow oil; IR (film) $\nu_{\max } 2967,2921,2854,1453$, 1382, 1090, 1070, 735, $697 \mathrm{~cm}^{-1} ;{ }^{1} \mathrm{H}$ NMR $\left(400 \mathrm{MHz}, \mathrm{CDCl}_{3}\right)$ $\delta$ 7.26-7.22 (5H, m), $5.32(1 \mathrm{H}, \mathrm{t}, J 6.8 \mathrm{~Hz}), 5.01(2 \mathrm{H}, \mathrm{m}), 4.41$ $(2 \mathrm{H}, \mathrm{s}), 3.95(2 \mathrm{H}, \mathrm{d}, J 6.8 \mathrm{~Hz}), 2.06-1.86(8 \mathrm{H}, \mathrm{m}), 1.58(3 \mathrm{H}, \mathrm{s})$, $1.55(3 \mathrm{H}, \mathrm{s}), 1.50(6 \mathrm{H}, \mathrm{s}) ;{ }^{13} \mathrm{C}$ NMR $\left(100 \mathrm{MHz}, \mathrm{CDCl}_{3}\right) \delta 140.4$,
138.6, 135.2, 131.2, 128.3 (2C), 127.8 (2C), 127.4, 124.3, 123.8, 120.8, 71.9, 66.6, 39.7, 39.6, 26.7, 26.3, 25.7, 17.6, 16.5, 16.0; HRMS $\left(\mathrm{CI}^{+}\right.$) calcd for $\mathrm{C}_{22} \mathrm{H}_{32} \mathrm{O} 312.2453[\mathrm{M}]^{+}$, found 312.2443.

(E)-1-Benzyloxy-2,6-dimethylhepta-2,6-diene (16c). (68\% yield). Colourless oil; IR (film) $\nu_{\max } 3068,3030,2918,1650$, 1454, 1374, 1090, 1072, 887, 735, $697 \mathrm{~cm}^{-1} ;{ }^{1} \mathrm{H}$ NMR $\left(400 \mathrm{MHz}, \mathrm{CDCl}_{3}\right) \delta 7.33-7.24(5 \mathrm{H}, \mathrm{m}), 5.42(1 \mathrm{H}, \mathrm{m}), 4.71(1 \mathrm{H}$, br s), $4.68(1 \mathrm{H}, \mathrm{br} \mathrm{s}), 4.43(2 \mathrm{H}, \mathrm{s}), 3.89(2 \mathrm{H}, \mathrm{s}), 2.18(2 \mathrm{H}, \mathrm{m})$, $2.06(2 \mathrm{H}, \mathrm{m}), 1.72(3 \mathrm{H}, \mathrm{s}), 1.68 \quad(3 \mathrm{H}, \mathrm{s}) ;{ }^{13} \mathrm{C} \quad \mathrm{NMR}$ $\left(100 \mathrm{MHz}, \mathrm{CDCl}_{3}\right) \delta 145.4,138.6,132.2,128.3(2 \mathrm{C}), 128.0$ (2C), 127.7, 127.4, 110.0, 76.2, 71.3, 37.4, 25.9, 22.4, 13.9; HRMS $\left(\mathrm{CI}^{+}\right)$calcd for $\mathrm{C}_{16} \mathrm{H}_{23} \mathrm{O} 231.1742[\mathrm{M}+\mathrm{H}]^{+}$, found 231.1749.

\section{General procedure for lithium carbenoid mediated cyclopropanation}

Preparation of compounds 4-13, 14a-c, 18a-c and 19a-19c. $n$-BuLi $(2.5 \mathrm{M}$ in hexane, $3.2 \mathrm{~mL}, 8.0 \mathrm{mmol}$ ) was added dropwise at $-78{ }^{\circ} \mathrm{C}$ to a solution of the corresponding allylic alcohol (1.0 mmol) and the corresponding dihaloalkane $(4.0 \mathrm{mmol})$ in dry pentane $(1.6 \mathrm{~mL})$ under an argon atmosphere. The mixture was stirred for 3 hours at $-78^{\circ} \mathrm{C}$, and then was allowed to warm to room temperature and stirred overnight. Then, water was added $(10 \mathrm{~mL})$, the layers were separated and the aqueous layer was extracted with pentane $(3 \times$ $50 \mathrm{~mL}$ ). The combined organic layers were dried over anhydrous sodium sulfate. Filtration and evaporation of the solvent under reduced pressure yielded the crude material that was purified by silica gel chromatography and HPLC to give the corresponding cyclopropane derivative in the yields and ratio shown in Tables 1 and 2. Yields were evaluated by GC.

$\left(\left(1 R^{*}, 2 R^{*}\right)\right.$-2-Methyl-2-(4-methylpent-3-en-1-yl)cyclopropyl) methanol (4). ( $33 \%$ yield from $\mathrm{CH}_{2} \mathrm{I}_{2}, 49 \%$ yield from $\mathrm{CH}_{2} \mathrm{Br}_{2}$ ). Spectroscopic data of compound $\mathbf{4}$ were identical to those described in the literature. ${ }^{57}$

$\left(\left(1 R^{*}, 2 R^{*}\right)\right.$-2-(2-(2,2-Dimethylcyclopropyl)ethyl)-2-methylcyclopropyl)methanol (5). (16\% yield). Spectroscopic data of compound $\mathbf{5}$ were identical to those described in the literature. ${ }^{58}$

$\left(\left(1 R^{*}, 2 S^{*}, 3 S^{*}\right)\right.$-3-Chloro-2-methyl-2-(4-methylpent-3-en-1-yl) cyclopropyl)methanol (6). (40\% yield). Colourless oil; $t_{\mathrm{R}}=$ $47.0 \mathrm{~min}$, petroleum ether: ethyl acetate $(90: 10)$, flow $=$

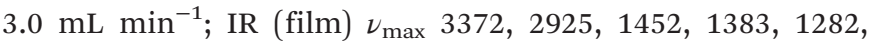
1026, 832, $718 \mathrm{~cm}^{-1} ;{ }^{1} \mathrm{H}$ NMR $\left(600 \mathrm{MHz}, \mathrm{C}_{6} \mathrm{D}_{6}\right) \delta 5.01(1 \mathrm{H}, \mathrm{m}$, $\left.\mathrm{CH}-3^{\prime \prime}\right), 3.59(1 \mathrm{H}, \mathrm{dd}, J 11.6,7.8 \mathrm{~Hz}, \mathrm{C} \underline{H} \mathrm{HOH}), 3.53(1 \mathrm{H}, \mathrm{dd}$, $J$ 11.6, $6.7 \mathrm{~Hz}, \mathrm{CHHOH}), 2.70\left(1 \mathrm{H}, \mathrm{d}, J 7.6 \mathrm{~Hz}, \mathrm{CH}_{-} 3^{\prime}\right), 1.91(2 \mathrm{H}$, q, $\left.J 7.4 \mathrm{~Hz}, \mathrm{CH}_{2}-2^{\prime \prime}\right), 1.63\left(3 \mathrm{H}, \mathrm{br} \mathrm{s}, \mathrm{CH}_{3}-5^{\prime \prime}\right), 1.48\left(3 \mathrm{H}, \mathrm{s}, \mathrm{CH}_{3}-1^{\prime \prime}\right.$ '), $1.05\left(1 \mathrm{H}, \mathrm{m}, \mathrm{CH}-1^{\prime \prime}\right), 0.99\left(3 \mathrm{H}, \mathrm{s},\left(\mathrm{C}_{3}\right) \mathrm{C}-2^{\prime}\right), 0.87(1 \mathrm{H}, \mathrm{m}$, CHH-1"), $0.77\left(1 \overline{\mathrm{H}}\right.$, ddd, $J$ 7.8, 7.6, $\left.6.7 \mathrm{~Hz}, \mathrm{H}-1^{\prime}\right) ;{ }^{13} \mathrm{C}$ NMR $\left(100 \mathrm{MHz}, \mathrm{C}_{6} \mathrm{D}_{6}\right) \delta 131.5,124.3,59.2,43.2,40.8,28.9,25.8$, 25.0, 24.1, 17.6, 12.4; HRMS $\left(\mathrm{CI}^{+}\right)$calcd for $\mathrm{C}_{11} \mathrm{H}_{19} \mathrm{OCl}[\mathrm{M}]^{+}$ 202.1124, found 202.1120.

$\left(\left(1 R^{*}, 2 S^{*}, 3 R^{*}\right)\right.$-3-Chloro-2-methyl-2-(4-methylpent-3-en-1-yl) cyclopropyl)methanol (7). (17\% yield). Colourless oil; $t_{\mathrm{R}}=$ 55.6 min, petroleum ether: ethyl acetate $(90: 10)$, flow $=$ $3.0 \mathrm{~mL} \mathrm{~min}^{-1}$; IR (film) $\nu_{\max } 3367,2919,1458,1377,1028$, 
$758 \mathrm{~cm}^{-1} ;{ }^{1} \mathrm{H}$ NMR $\left(400 \mathrm{MHz}, \mathrm{C}_{6} \mathrm{D}_{6}\right) \delta 5.19\left(1 \mathrm{H}, \mathrm{m}, \mathrm{CH}-3^{\prime \prime}\right)$, $3.28(1 \mathrm{H}, \mathrm{m}, \mathrm{CHHOH}), 3.00(1 \mathrm{H}, \mathrm{m}, \mathrm{CH} H \mathrm{HH}), 2.45(1 \mathrm{H}, \mathrm{d}$, $\left.J 4.0 \mathrm{~Hz}, \mathrm{C}-\mathbf{H}^{\prime}\right), 2.19$ (1H, m, C $1.67(3 \mathrm{H}, \mathrm{s}), 1.56(3 \mathrm{H}, \mathrm{s}), 1.59-1.54\left(2 \mathrm{H}, \mathrm{CH}_{2}-1^{\prime \prime}\right), 0.97(1 \mathrm{H}$, ddd, $J$ 8.5, 6.2, $\left.4.0 \mathrm{~Hz}, \mathrm{CH}-1^{\prime}\right), 0.76\left(3 \mathrm{H}, \mathrm{s},\left(\mathrm{C}_{3}\right) \mathrm{C}-2^{\prime}\right) ;{ }^{13} \mathrm{C}$ NMR $\left(100 \mathrm{MHz}, \mathrm{C}_{6} \mathrm{D}_{6}\right) \delta 131.5,124.8,60.9,44.1,36.5,35.5,26.0$, $25.8,25.5,17.7,16.6$; HRMS $\left(\mathrm{APGC}^{+}\right)$calcd for $\mathrm{C}_{11} \mathrm{H}_{18} \mathrm{Cl}$ $\left[\mathrm{M}+\mathrm{H}-\mathrm{H}_{2} \mathrm{O}\right]^{+}$185.1097, found 185.1111.

$\left(\left(1 R^{*}, 2 S^{*}, 3 R^{*}\right)-3\right.$-Chloro-2-(2-((1S $\left.S^{*}, 3 R^{*}\right)$-3-chloro-2,2-dimethylcyclopropyl)ethyl)-2-methylcyclopropyl)methanol (8). (7\% yield). Colourless oil; $t_{\mathrm{R}}=63.5 \mathrm{~min}$, petroleum ether: ethyl

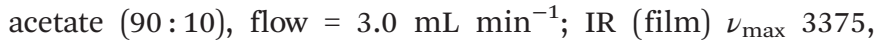
2928, 1455, 1283, 1019, $725 \mathrm{~cm}^{-1}$; ${ }^{1} \mathrm{H}$ NMR $\left(500 \mathrm{MHz}, \mathrm{CDCl}_{3}\right)$ $\delta 3.78(1 \mathrm{H}, \mathrm{dd}, J 11.6,6.6 \mathrm{~Hz}, \mathrm{C} \underline{\mathrm{H} H O H}), 3.56(1 \mathrm{H}, \mathrm{dd}, J 11.6$, $8.3 \mathrm{~Hz}, \mathrm{CH} \underline{\mathrm{HOH}}), 2.79$ (1H, d, J $\left.4.0 \mathrm{~Hz}, \mathrm{C} \underline{\mathrm{H}}-3^{\prime}\right), 2.57$ (1H, d, $\left.J 3.8 \mathrm{~Hz}, \mathrm{CH}-3^{\prime \prime \prime}\right) 1.63-1.56$ (3H, $\mathrm{C}-\mathrm{H}-1^{\prime \prime}$ and $\left.\mathrm{CH}_{2}-2^{\prime \prime}\right), 1.47(1 \mathrm{H}$, $\left.\mathrm{m}, \mathrm{CHH}-1^{\prime \prime}\right), 1.23\left(3 \mathrm{H}, \mathrm{s}, \mathrm{CH}_{3}-4^{\prime \prime \prime}\right), 1.18(1 \mathrm{H}, \mathrm{ddd}, J$ 8.3, 6.6, 4.0, $\left.\left.\mathrm{C}-\underline{H}^{\prime}\right)^{\prime}\right), 1.11\left(3 \mathrm{H}, \mathrm{s},\left(\mathrm{CH}_{3}\right) \mathrm{C}-2^{\prime}\right), 1.09\left(3 \mathrm{H}, \mathrm{s}, \mathrm{CH}_{3}-5^{\prime \prime \prime}\right), 0.79(1 \mathrm{H}$, ddd, $J$ 7.7, 6.3, 4.0, $\left.\mathrm{CH}^{-1} \mathbf{1}^{\prime \prime}\right) ;{ }^{13} \mathrm{C}$ NMR (125 MHz, $\left.\mathrm{CDCl}_{3}\right) \delta$ 61.4, 45.8, 43.8, 35.8, 35.1, 33.6, 25.9, 24.9, 22.6, 22.0, 19.5, 16.9; HRMS (APGC ${ }^{+}$) calcd for $\mathrm{C}_{12} \mathrm{H}_{19} \mathrm{ClO}[\mathrm{M}+\mathrm{H}-\mathrm{HCl}]^{+}$215.1203, found 215.1203; calcd for $\mathrm{C}_{12} \mathrm{H}_{18} \mathrm{O}[\mathrm{M}+\mathrm{H}-2 \mathrm{HCl}]^{+}$179.1430, found 179.1431 .

$\left(\left(1 R^{*}, 3 S^{*}\right)\right.$-2,2-Dichloro-3-methyl-3-(4-methylpent-3-en-1-yl) cyclopropyl)methanol (9). (19\% yield). Colourless oil; $t_{\mathrm{R}}=$ $41.0 \mathrm{~min}$, petroleum ether: ethyl acetate $(90: 10)$, flow $=$ $3.0 \mathrm{~mL} \mathrm{~min}{ }^{-1}$; IR (film) $\nu_{\max } 3389,2964,2929,1720,1456$, $1385,1032,832 \mathrm{~cm}^{-1} ;{ }^{1} \mathrm{H}$ NMR $\left(600 \mathrm{MHz}, \mathrm{CDCl}_{3}\right) \delta 5.10(1 \mathrm{H}$, m, $\left.\mathrm{C}-\underline{-}^{\prime \prime}\right), 3.78$ (1H, m, C (1H, m, CHHH-2"), $2.11\left(1 \mathrm{H}, \mathrm{m}, \mathrm{CH}-\underline{H}_{-2}{ }^{\prime \prime}\right), 1.69\left(3 \mathrm{H}, \mathrm{s}, \mathrm{CH}_{3}-5^{\prime \prime}\right)$, 1.64-1.61 $\left(2 \mathrm{H}, \mathrm{C}_{2}-1^{\prime \prime}\right), 1.62\left(3 \mathrm{H}, \mathrm{s}, \mathrm{C}_{3}-1^{\prime \prime \prime}\right), 1.51(1 \mathrm{H}, \mathrm{dd}$, $J$ 8.0, $\left.6.6 \mathrm{~Hz}, \mathrm{C} \underline{\mathrm{H}}-1^{\prime}\right), 1.22\left(3 \mathrm{H}, \mathrm{s},\left(\mathrm{CH}_{3}\right) \mathrm{C}-3^{\prime}\right) ;{ }^{1} \mathrm{H}$ NMR $(400 \mathrm{MHz}$, $\left.\mathrm{C}_{6} \mathrm{D}_{6}\right) \delta 5.08\left(1 \mathrm{H}, \mathrm{m}, \mathrm{CH}-3^{\prime \prime}\right), 3.44(1 \mathrm{H}, \mathrm{m}, \mathrm{C} \underline{\mathrm{HOH}}), 3.31(1 \mathrm{H}$, $\mathrm{m}, \mathrm{CH} \underline{\mathrm{HOH}}), 2.12\left(1 \mathrm{H}, \mathrm{m}, \mathrm{C} \underline{\mathrm{H}}-2^{\prime \prime}\right), 1.98\left(1 \mathrm{H}, \mathrm{m}, \mathrm{CH} \underline{\mathrm{H}}-2^{\prime \prime}\right)$, $1.64\left(3 \overline{\mathrm{H}}, \mathrm{s}, \mathrm{CH}_{3}-5^{\prime \prime}\right), 1.51\left(3 \mathrm{H}, \mathrm{s}, \mathrm{CH}_{3}-1^{\prime \prime \prime}\right), 1.50\left(2 \mathrm{H}, \mathrm{CH}_{2}-1^{\prime \prime}\right)$, $1.26\left(1 \mathrm{H}, \mathrm{t}, J 7.2 \mathrm{~Hz}, \mathrm{C}-1^{\prime}\right), 0.96\left(3 \mathrm{H}, \mathrm{s},\left(\mathrm{CH}_{3}\right) \mathrm{C}-3^{\prime}\right) ;{ }^{13} \mathrm{C} \mathrm{NMR}$ $\left(100 \mathrm{MHz}, \mathrm{C}_{6} \mathrm{D}_{6}\right) \delta 132.0,124.0,71.1,59.4,39.8,38.6,32.8$, 25.8, 25.4, 17.7, 14.2; HRMS $\left(\right.$ APGC $^{+}$) calcd for $\mathrm{C}_{11} \mathrm{H}_{17} \mathrm{Cl}_{2}$ $\left[\mathrm{M}+\mathrm{H}-\mathrm{H}_{2} \mathrm{O}\right]^{+}$219.0707, found 219.0712; calcd for $\mathrm{C}_{11} \mathrm{H}_{8} \mathrm{OCl}$ $[\mathrm{M}+\mathrm{H}-\mathrm{HCl}]^{+}$201.1046, found 201.1046; calcd for $\mathrm{C}_{11} \mathrm{H}_{16} \mathrm{Cl}$ $\left[\mathrm{M}+\mathrm{H}-\mathrm{H}_{2} \mathrm{O}-\mathrm{HCl}\right]^{+}$183.0941, found 183.0947.

(E)-5-(2,2-Dichloro-3,3-dimethylcyclopropyl)-3-methylpent-2en-1-ol (10). ${ }^{59}$ (19\% yield). Colourless oil; $t_{\mathrm{R}}=51.9 \mathrm{~min}$, petroleum ether : ethyl acetate $(90: 10)$, flow $=3.0 \mathrm{~mL} \mathrm{~min}^{-1}$; IR (film) $\nu_{\max } 3345,2988,2957,2870,1735,1670,1453,1376$, 999, $830 \mathrm{~cm}^{-1}$; ${ }^{1} \mathrm{H}$ NMR $\left(400 \mathrm{MHz}, \mathrm{CDCl}_{3}\right) \delta 5.45(1 \mathrm{H}, \mathrm{t}, J 7.0$ $\mathrm{Hz}, \mathrm{C} \underline{\mathrm{H}}-2), 4.16\left(2 \mathrm{H}, \mathrm{d}, J 7.0 \mathrm{~Hz}, \mathrm{C}_{2}-1\right), 2.16(1 \mathrm{H}, \mathrm{m}, \mathrm{CH} H-4)$, $2.11(\overline{1} \mathrm{H}, \mathrm{m}, \mathrm{CH}-4), 1.69\left(3 \mathrm{H}, \mathrm{s},\left(\overline{\mathrm{C}}_{3}\right) \mathrm{C}-3\right), 1.57\left(2 \mathrm{H}, \overline{\mathrm{CH}}_{2}-5\right)$, $1.33\left(3 \mathrm{H}, \mathrm{s},\left(\mathrm{CH}_{3}\right)\left(\mathrm{CH}_{3}\right) \mathrm{C}-3^{\prime}\right), 1.15\left(3 \mathrm{H}, \mathrm{s},\left(\mathrm{CH}_{3}\right)\left(\mathrm{CH}_{3}\right) \mathrm{C}-3^{\prime}\right), 1.10$ $\left(1 \mathrm{H}, \mathrm{m}, \mathrm{CH}-1^{\prime}\right) ;{ }^{13} \mathrm{C}$ NMR $\left(100 \mathrm{MHz}, \mathrm{CDCl}_{3}\right) \delta 138.7,124.3$, 72.0, 59.4, 38.3, 38.2, 28.4, 24.9, 24.1, 17.2, 16.3; HRMS $\left(\mathrm{APGC}^{+}\right.$) calcd for $\mathrm{C}_{11} \mathrm{H}_{19} \mathrm{OCl}_{2}[\mathrm{M}+\mathrm{H}]^{+}$237.0813, found 237.0809; calcd for $\mathrm{C}_{11} \mathrm{H}_{17} \mathrm{Cl}_{2}\left[\mathrm{M}+\mathrm{H}-\mathrm{H}_{2} \mathrm{O}\right]^{+}$219.0707, found 219.0710; calcd for $\mathrm{C}_{11} \mathrm{H}_{8} \mathrm{OCl}[\mathrm{M}+\mathrm{H}-\mathrm{HCl}]^{+}$201.1046, found 201.1050; calcd for $\mathrm{C}_{11} \mathrm{H}_{16} \mathrm{Cl}\left[\mathrm{M}+\mathrm{H}-\mathrm{H}_{2} \mathrm{O}-\mathrm{HCl}\right]^{+}$183.0941, found 183.0929 . $\left(\left(1 R^{*}, 3 S^{*}\right)\right.$-2,2-Dichloro-3-(2-( $\left(S^{*}\right)$-2,2-dichloro-3,3-dimethylcyclopropyl)ethyl)-3-methylcyclopropyl)methanol (11). ${ }^{60}(37 \%$ yield). Colourless oil; $t_{\mathrm{R}}=54.4 \mathrm{~min}$, petroleum ether: ethyl acetate $(90: 10)$, flow $=3.0 \mathrm{~mL} \mathrm{~min}{ }^{-1}$; IR (film) $\nu_{\max } 3342$, 2928, 1458, 1038, $834 \mathrm{~cm}^{-1} ;{ }^{1} \mathrm{H}$ NMR $\left(400 \mathrm{MHz}, \mathrm{CDCl}_{3}\right) \delta 3.78$ (2H, m, $\left.\underline{\mathrm{C}}_{2}-1\right), 1.85\left(1 \mathrm{H}, \mathrm{m}, \mathrm{C} \underline{\mathrm{H}}-\mathrm{1}^{\prime \prime}\right), 1.68-1.53\left(4 \mathrm{H}, \mathrm{H}-1^{\prime}\right.$, $\mathrm{CH} \underline{\mathrm{H}}-\mathrm{1}^{\prime \prime}$ and $\left.\mathrm{C}_{2}-2^{\prime \prime}\right), 1.34\left(3 \mathrm{H}, \mathrm{s}, \mathrm{CH}_{3}-4^{\prime \prime \prime}\right), 1.23\left(3 \mathrm{H}, \mathrm{s},\left(\mathrm{C}_{3}\right)\right.$ C-3'), $1.18\left(3 \mathrm{H}, \mathrm{s}, \mathrm{CH}_{3}-5^{\prime \prime \prime}\right), 1.13\left(1 \mathrm{H}, \mathrm{t}, J 7.0 \mathrm{~Hz}, \mathrm{C}-\mathbf{H}^{\prime \prime \prime}\right)$; ${ }^{13} \mathrm{C}$ NMR $\left(100 \mathrm{MHz}, \mathrm{CDCl}_{3}\right) \delta 71.7,70.1,59.7,39.4,38.2,37.3$, $32.7,28.5,24.9,22.5,17.2,14.4$; HRMS $\left(\mathrm{APGC}^{+}\right)$calcd for $\mathrm{C}_{12} \mathrm{H}_{16} \mathrm{Cl}_{3} 265.0318\left[\mathrm{M}+\mathrm{H}-\mathrm{H}_{2} \mathrm{O}-\mathrm{HCl}\right]^{+}$, found 265.0302; calcd for $\mathrm{C}_{12} \mathrm{H}_{17} \mathrm{OCl}_{2}[\mathrm{M}+\mathrm{H}-2 \mathrm{HCl}]^{+}$247.0619, found 247.0611; calcd for $\mathrm{C}_{12} \mathrm{H}_{15} \mathrm{Cl}_{2}\left[\mathrm{M}+\mathrm{H}-\mathrm{H}_{2} \mathrm{O}-2 \mathrm{HCl}\right]^{+}$ 229.0551 , found 229.0539 .

$\left(1 R^{*}, 2 S^{*}, 3 S^{*}\right)$-2-Chloro-2-ethyl-3-methyl-3-(4-methylpent-3en-1-yl)cyclopropyl)methanol (12). (32\% yield). Colourless oil; $t_{\mathrm{R}}=12.0 \mathrm{~min}$, petroleum ether : ethyl acetate $(90: 10)$, flow $=$

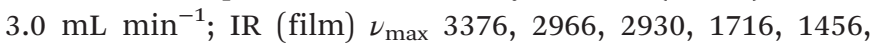
1378, 1262, 1106, 1020, $870 \mathrm{~cm}^{-1} ;{ }^{1} \mathrm{H}$ NMR (400 MHz, $\mathrm{C}_{6} \mathrm{D}_{6}$ ) $\delta 5.08\left(1 \mathrm{H}, \mathrm{t}, J 7.3 \mathrm{~Hz}, \mathrm{C} \underline{\mathrm{H}}-3\right.$ "), $3.64\left(2 \mathrm{H}, \mathrm{d}, J 7.4 \mathrm{~Hz}, \mathrm{C}_{2} \mathrm{OH}\right)$, $2.00\left(2 \mathrm{H}, \mathrm{q}, J 7.3 \mathrm{~Hz}, \mathrm{CH}_{2}-2^{\prime \prime}\right), 1.70\left(1 \mathrm{H}, \mathrm{m}, \mathrm{CH}_{3} \mathrm{CH}-\mathrm{HCCl}\right), 1.66$ $\left(3 \mathrm{H}, \mathrm{s}, \mathrm{CH}_{3}-^{\prime \prime \prime}\right), 1.57\left(1 \mathrm{H}, \mathrm{m}, \mathrm{CH}_{3} \mathrm{CH} \underline{\mathrm{HCCl}}\right), 1.52\left(3 \mathrm{H}, \mathrm{s}, \mathrm{CH}_{3^{-}}\right.$ $\left.5^{\prime \prime}\right), 1.28\left(1 \mathrm{H}, \mathrm{m}, \mathrm{CHH}-1^{\prime \prime}\right), 1.14\left(1 \mathrm{H}, \overline{\mathrm{m}}, \mathrm{CHH}-1^{\prime \prime}\right), 1.14(3 \mathrm{H}, \mathrm{s}$, $\left.\left(\mathrm{CH}_{3}\right) \mathrm{C}-3^{\prime}\right), 1.07\left(3 \mathrm{H}, \mathrm{t}, J 7.2 \mathrm{~Hz}, \mathrm{CH}_{3} \mathrm{CHHCCl}\right), 0.57(1 \mathrm{H}, \mathrm{t}, J 7.4$ $\left.\mathrm{Hz}, \mathrm{CH}-1^{\prime}\right) ;{ }^{13} \mathrm{C}$ NMR $\left(100 \mathrm{MHz}, \mathrm{C}_{6} \mathrm{D}_{6}\right) \delta 131.5,124.6,60.6$, 60.5, 37.2, 34.7, 31.4, 29.4, 25.8, 25.8, 17.7, 15.4, 11.6; HRMS $\left(\mathrm{CI}^{+}\right)$calcd for $\mathrm{C}_{13} \mathrm{H}_{22} \mathrm{OCl}\left[\mathrm{M}+\mathrm{H}-\mathrm{H}_{2}\right]^{+}$229.1359, found 229.1358.

$\left(1 R^{*}, 2 R^{*}, 3 S^{*}\right)$-2-Chloro-2-ethyl-3-methyl-3-(4-methylpent-3en-1-yl)cyclopropyl)methanol (13). (16\% yield). Colourless oil; $t_{\mathrm{R}}=15.8 \mathrm{~min}$, petroleum ether : ethyl acetate $(90: 10)$, flow $=$

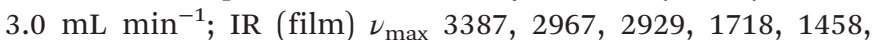
$1378,1105,866 \mathrm{~cm}^{-1} ;{ }^{1} \mathrm{H}$ NMR $\left(400 \mathrm{MHz}, \mathrm{CDCl}_{3}\right) \delta 5.13(1 \mathrm{H}, \mathrm{t}$, $\left.J 7.2 \mathrm{~Hz}, \mathrm{C}-\underline{-}^{\prime \prime}\right), 3.77$ (1H, dd, $J$ 11.6, $7.2 \mathrm{~Hz}, \mathrm{C} \underline{\mathrm{HOH}}$ ), 3.57 (1H, dd, $J$ 11.6, $8.2 \mathrm{~Hz}, \mathrm{CH} \underline{\mathrm{HOH}}), 2.13\left(2 \mathrm{H}, \mathrm{m}, \mathrm{C}_{2}-2^{\prime \prime}\right), 1.86$ $\left(1 \mathrm{H}, \mathrm{dq}, J\right.$ 14.6, $\left.7.3 \mathrm{~Hz}, \mathrm{CH}_{3} \mathrm{CH} H \mathrm{HCl}\right), 1.75(1 \mathrm{H}, \mathrm{m}$, $\left.\mathrm{CH}_{3} \mathrm{CH} \underline{\mathrm{HCCl}}\right), 1.71-1.66$ (1H, m, $\left.\mathrm{C} \underline{\mathrm{H}}-1^{\prime \prime}\right), 1.68\left(3 \mathrm{H}, \mathrm{s}, \mathrm{C}_{3}-1^{\prime \prime}\right.$ '), $1.62\left(3 \mathrm{H}, \mathrm{s}, \mathrm{CH}_{3}-5^{\prime \prime}\right), 1.62-1.56\left(1 \mathrm{H}, \mathrm{m}, \mathrm{CH}-\underline{H}^{\prime \prime}\right), 1.28(1 \mathrm{H}$, $\mathrm{dd}, J$ 8.2, $\left.\left.7.2 \mathrm{~Hz}, \mathrm{C} \underline{H}^{\prime}\right)^{\prime}\right), 1.09\left(3 \mathrm{H}, \mathrm{s},\left(\mathrm{CH}_{3}\right) \mathrm{C}-3^{\prime}\right), 1.09(3 \mathrm{H}, \mathrm{t}$, $J$ 7.3, $\left.\mathrm{CH}_{3} \mathrm{CHHCCl}\right) ;{ }^{\overline{13}} \mathrm{C} \mathrm{NMR}\left(100 \mathrm{MHz}, \mathrm{CDCl}_{3}\right) \delta 131.7,124.2$, 59.4, 58.5, 39.0, 38.0, 29.0, 26.5, 25.7, 25.3, 17.7, 13.1, 11.2; HRMS $\left(\mathrm{CI}^{+}\right)$calcd for $\mathrm{C}_{13} \mathrm{H}_{22} \mathrm{OCl}\left[\mathrm{M}+\mathrm{H}-\mathrm{H}_{2}\right]^{+}$229.1359, found 229.1354 .

$\left(\left(1 R^{*}, 3 S^{*}\right)-2,2,3-T r i m e t h y l-3-(4-m e t h y l p e n t-3-e n-1-y l) c y c l o-\right.$ propyl)methanol (14a). (58\% yield). Colourless oil; $t_{\mathrm{R}}=$ $25 \mathrm{~min}$, petroleum ether : ethyl acetate $(85: 15)$, flow $=3.0 \mathrm{~mL}$ $\min ^{-1}$; IR (film) $\nu_{\max } 3444,2922,1645,1010 \mathrm{~cm}^{-1}$; ${ }^{1} \mathrm{H}$ NMR $\left(400 \mathrm{MHz}, \mathrm{CDCl}_{3}\right) \delta 5.10\left(1 \mathrm{H}, \mathrm{t}, J 6.6 \mathrm{~Hz}, \mathrm{C}-3^{\prime \prime}\right), 3.65(1 \mathrm{H}, \mathrm{dd}$, $J 11.4,7.7 \mathrm{~Hz}, \mathrm{C} \underline{\mathrm{H} H O H}), 3.63(1 \mathrm{H}, \mathrm{dd}, J 11.4,7.4 \mathrm{~Hz}, \mathrm{CH} \underline{\mathrm{HOH}})$, $2.05\left(2 \mathrm{H}, \mathrm{m}, \mathrm{C}_{2}-2^{\prime \prime}\right), 1.67\left(3 \mathrm{H}, \mathrm{s}, \mathrm{C}_{3}-1^{\prime \prime \prime}\right), 1.60\left(3 \mathrm{H}, \mathrm{s}, \mathrm{C}_{3}-\right.$ $\left.5^{\prime \prime}\right), 1.36\left(2 \mathrm{H}, \mathrm{m}, \mathrm{CH}_{2}-1^{\prime \prime}\right), 1.12 \quad\left(3 \mathrm{H}, \mathrm{s},\left(\mathrm{CH}_{3}\right)\left(\mathrm{CH}_{3}\right) \mathrm{C}-2^{\prime}\right)$, $1.02\left(3 \mathrm{H}, \mathrm{s},\left(\mathrm{CH}_{3}\right) \mathrm{C}-3^{\prime}\right), 1.00\left(3 \mathrm{H}, \mathrm{s},\left(\mathrm{CH}_{3}\right)\left(\mathrm{CH}_{3}\right) \mathrm{C}-2^{\prime}\right), 0.54(1 \mathrm{H}$, $\left.\left.\mathrm{t}, J 7.7 \mathrm{~Hz}, \mathrm{CH}_{-1}\right)^{\prime}\right) ;{ }^{13} \mathrm{C} \mathrm{NMR}\left(100 \mathrm{MHz}, \mathrm{CDCl}_{3}\right) \delta 131.2,124.8$, 60.9, 37.6, 35.2, 26.1, 25.8, 25.7, 23.6, 22.7, 17.6, 17.3, 13.7; HRMS $\left(\mathrm{CI}^{+}\right)$calcd for $\mathrm{C}_{13} \mathrm{H}_{23} \mathrm{O}[\mathrm{M}-\mathrm{H}]^{+}$195.1749, found 195.1754. 
tert-Butyldimethyl $\left(\left(\left(1 R^{*}, 3 S^{*}\right)\right.\right.$-2,2,3-trimethyl-3-(4-methylpent3-en-1-yl)cyclopropyl)methoxy)silane (14b). (45\% yield). Colourless oil; $t_{\mathrm{R}}=11 \mathrm{~min}$, petroleum ether: ethyl acetate

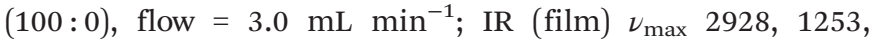
$835 \mathrm{~cm}^{-1} ;{ }^{1} \mathrm{H}$ NMR (400 MHz, $\left.\mathrm{CDCl}_{3}\right) \delta 5.10\left(1 \mathrm{H}, \mathrm{m}, \mathrm{C} \underline{\mathrm{H}}-3^{\prime \prime}\right)$, $3.64(1 \mathrm{H}, \mathrm{dd}, J 11.0,7.4 \mathrm{~Hz}, \mathrm{C} \underline{\mathrm{HHOH}}), 3.59(1 \mathrm{H}, \mathrm{dd}, J 11.0,7.4$ $\mathrm{Hz}, \mathrm{CH} \underline{\mathrm{HOH}}), 2.01\left(2 \mathrm{H}, \mathrm{m}, \mathrm{CH}_{2}-2^{\prime \prime}\right), 1.67\left(3 \mathrm{H}, \mathrm{d}, J 1.2 \mathrm{~Hz}, \mathrm{CH}_{3}-\right.$ $\left.1^{\prime \prime \prime}\right), 1.60\left(3 \mathrm{H}, \mathrm{s}, \mathrm{CH}_{3}-5^{\prime \prime}\right), 1.32\left(2 \mathrm{H}, \mathrm{m}, \mathrm{C}_{2}-1^{\prime \prime}\right), 1.09(3 \mathrm{H}, \mathrm{s}$, $\left.\left(\mathrm{CH}_{3}\right)\left(\mathrm{CH}_{3}\right) \mathrm{C}-2^{\prime}\right), 0.97\left(3 \mathrm{H}, \mathrm{s},\left(\mathrm{CH}_{3}\right) \mathrm{C}-3^{\prime}\right), 0.96\left(3 \mathrm{H}, \mathrm{s},\left(\mathrm{CH}_{3}\right)\right.$ $\left.\left(\mathrm{CH}_{3}\right) \mathrm{C}-2^{\prime}\right), 0.88\left(9 \mathrm{H}, \mathrm{s}, \mathrm{SiC}\left(\mathrm{CH}_{3}\right)_{3}\right), 0.46\left(1 \mathrm{H}, \mathrm{t}, J\right.$ 7.4 Hz, C$\left.-1^{\prime}\right)$, $0.03\left(6 \mathrm{H}, \mathrm{s}, \mathrm{Si}\left(\mathrm{CH}_{3}\right)_{2}\right) ;{ }^{13} \mathrm{C}$ NMR $\left(100 \mathrm{MHz}, \mathrm{CDCl}_{3}\right) \delta 130.9$, 125.1, 60.8, 38.0, 34.9, 26.0 (3C), 25.80, 25.75, 25.71, 23.6, 22.2, 18.2, 17.6, 17.4, 13.8, -5.0, -5.1; HRMS $\left(\mathrm{CI}^{+}\right)$calcd for $\mathrm{C}_{19} \mathrm{H}_{38} \mathrm{OSi}[\mathrm{M}]^{+} 310.2692$, found 310.2674 .

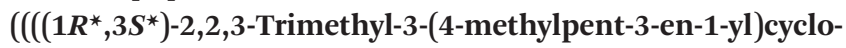
propyl)methoxy)methyl)benzene (14c). (81\% yield). Yellow oil; $t_{\mathrm{R}}=9.0 \mathrm{~min}$, petroleum ether : ethyl acetate $(100: 0)$, flow $=$

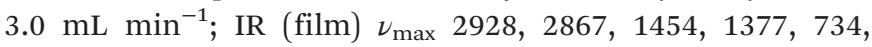
$698 \mathrm{~cm}^{-1} ;{ }^{1} \mathrm{H}$ NMR $\left(400 \mathrm{MHz}, \mathrm{CDCl}_{3}\right) \delta 7.34-7.25(5 \mathrm{H}, \mathrm{m}$, $\left.\mathrm{H}_{\text {atom }}\right), 5.11\left(1 \mathrm{H}, \mathrm{m}, \mathrm{C} \underline{\mathrm{H}}-3^{\prime \prime}\right), 4.50\left(2 \mathrm{H}, \mathrm{s}, \mathrm{C}_{2} \mathrm{Ph}\right), 3.50(1 \mathrm{H}, \mathrm{dd}$,

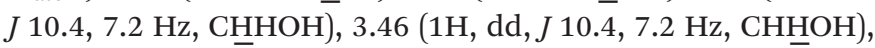
$2.04\left(2 \mathrm{H}, \mathrm{m}, \mathrm{CH}_{2}-2^{\prime \prime}\right), 1.68\left(3 \mathrm{H}, \mathrm{s}, \mathrm{C}_{3}-^{\prime \prime \prime}\right), 1.61\left(3 \mathrm{H}, \mathrm{s}, \mathrm{C}_{3}-\right.$ $\left.5^{\prime \prime}\right), 1.45\left(1 \mathrm{H}, \mathrm{m}, \mathrm{CHH}-1^{\prime \prime}\right), 1.32\left(1 \mathrm{H}, \mathrm{m}, \mathrm{CHH}-1^{\prime \prime}\right), 1.13(3 \mathrm{H}, \mathrm{s}$, $\left.\left(\mathrm{CH}_{3}\right)\left(\mathrm{CH}_{3}\right) \mathrm{C}-2^{\prime}\right), 0.98\left(3 \mathrm{H}, \mathrm{s},\left(\mathrm{CH}_{3}\right) \mathrm{C}-3^{\prime}\right), 0.96\left(3 \mathrm{H}, \mathrm{s},\left(\mathrm{CH}_{3}\right)\right.$ $\left.\left(\mathrm{CH}_{3}\right) \mathrm{C}-2^{\prime}\right), 0.57\left(1 \mathrm{H}, \mathrm{t}, J 7.2 \mathrm{~Hz}, \underline{\mathrm{C}}_{-}-1^{\prime}\right) ;{ }^{13} \mathrm{C}$ NMR $(100 \mathrm{MHz}$, $\left.\mathrm{CDCl}_{3}\right) \delta 138.9,130.9,128.3$ (2C), 127.6 (2C), 127.4, 124.9, 72.4, 68.0, 38.0, 32.2, 25.9, 25.72, 25.70, 23.5, 22.4, 17.6, 17.4, 13.9; HRMS $\left(\mathrm{CI}^{+}\right)$calcd for $\mathrm{C}_{20} \mathrm{H}_{30} \mathrm{O}[\mathrm{M}]^{+}$286.2297, found 286.2297.

$\left(\left(1 R^{*}, 2 S^{*}\right)-2^{\prime}-((E)-4,8-D i m e t h y l n o n a-3,7-d i e n-1-y l)-2,3,3-t r i-\right.$ methylcyclopropyl)methanol (18a). (66\% yield). Yellow oil; $t_{\mathrm{R}}=30 \mathrm{~min}$, petroleum ether : ethyl acetate $(90: 10)$, flow $=$

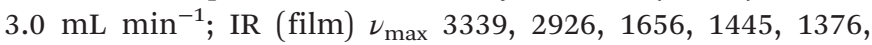
$1012 \mathrm{~cm}^{-1} ;{ }^{1} \mathrm{H}$ NMR $\left(400 \mathrm{MHz}, \mathrm{CDCl}_{3}\right) \delta 5.09(2 \mathrm{H}, \mathrm{m}, \mathrm{C} \underline{\mathrm{H}}-3 "$ and $\left.\mathrm{C}_{-}-7^{\prime \prime}\right), 3.66(1 \mathrm{H}, \mathrm{dd}, J 11.4,7.6 \mathrm{~Hz}, \mathrm{C} \underline{\mathrm{HOH}}), 3.62(1 \mathrm{H}$, dd, $J 11.4,7.6 \mathrm{~Hz}, \mathrm{CH}-\underline{\mathrm{HOH}}), 2.09-1.94\left(4 \mathrm{H}, \mathrm{m}, \mathrm{C}_{2}-2\right.$ " and $\left.\mathrm{C}_{2}-6^{\prime \prime}\right), 1.67\left(3 \mathrm{H}, \mathrm{s}, \mathrm{C}_{3}-9^{\prime \prime}\right), 1.60\left(3 \mathrm{H}, \mathrm{s}, \mathrm{CH}_{3}-1^{\prime \prime \prime}\right), 1.59(3 \mathrm{H}, \mathrm{s}$, $\left.\left(\mathrm{C}_{3}\right) \mathrm{C}-4 "\right), 1.44-1.29\left(2 \mathrm{H}, \mathrm{m}, \mathrm{CH}_{2}-1^{\prime \prime}\right.$ and $\left.\mathrm{CH}_{2}-5 "\right), 1.10(3 \mathrm{H}, \mathrm{s}$, $\left.\left(\mathrm{C}_{3}\right)\left(\mathrm{CH}_{3}\right) \mathrm{C}-3^{\prime}\right), 1.02\left(3 \mathrm{H}, \mathrm{s},\left(\mathrm{C}_{3}\right) \mathrm{C}-2^{\prime}\right), 1.00\left(3 \mathrm{H}, \mathrm{s},\left(\mathrm{CH}_{3}\right)\right.$ $\left.\left(\mathrm{CH}_{3}\right) \mathrm{C}-3^{\prime}\right), 0.54\left(1 \mathrm{H}, \mathrm{t}, J 7.6 \mathrm{~Hz}, \underline{\mathrm{C}}_{-1} \mathbf{1}^{\prime}\right) ;{ }^{13} \mathrm{C}$ NMR $(100 \mathrm{MHz}$, $\left.\mathrm{CDCl}_{3}\right) \delta 134.8,131.3,124.6,124.3,60.9,39.7,37.6,35.2,26.7$, 26.2, 25.7 (2C), 23.6, 22.7, 17.7, 17.3, 15.9, 13.7; HRMS $\left(\mathrm{CI}^{+}\right)$ calcd for $\mathrm{C}_{18} \mathrm{H}_{32} \mathrm{O}[\mathrm{M}]^{+}$264.2453, found 264.2449.

tert-Butyl $\left(\left(\left(1 R^{*}, 2 S^{*}\right)-2-((E)-4,8\right.\right.$-dimethylnona-3,7-dien-1-yl)2,3,3-trimethylcyclopropyl)methoxy)dimethylsilane

(18b). ( $45 \%$ yield). Yellow oil; $t_{\mathrm{R}}=15 \mathrm{~min}$, petroleum ether: ethyl

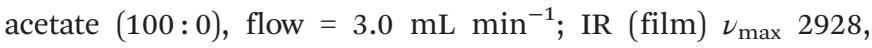
$1647,1255,837 \mathrm{~cm}^{-1} ;{ }^{1} \mathrm{H}$ NMR $\left(400 \mathrm{MHz}, \mathrm{CDCl}_{3}\right) \delta 5.12(2 \mathrm{H}$, $\mathrm{m}, \mathrm{C} \underline{\mathrm{H}}-3^{\prime \prime}$ and $\left.\mathrm{C}_{-}-\mathrm{7}^{\prime \prime}\right), 3.64(1 \mathrm{H}, \mathrm{dd}, J 11.1,7.3 \mathrm{~Hz}, \mathrm{C} \underline{\mathrm{H}} \mathrm{HOH})$, $3.59(1 \mathrm{H}, \mathrm{dd}, J 11.1,7.3 \mathrm{~Hz}, \mathrm{CH} \underline{\mathrm{HOH}}), 2.08-1.94\left(4 \mathrm{H}, \overline{\mathrm{m}}, \mathrm{C}_{2^{-}}\right.$ 2" and $\left.\mathrm{C}_{2}-6^{\prime \prime}\right), 1.68\left(3 \mathrm{H}, \mathrm{s}, \mathrm{C}_{3}-9^{\prime \prime}\right), 1.59\left(6 \mathrm{H}, \mathrm{s}, \mathrm{C}_{3}-1^{\prime \prime \prime}\right.$ and $\left.\left(\mathrm{C}_{3}\right) \mathrm{C}-4 "\right), 1.39-1.26\left(4 \mathrm{H}, \mathrm{m}, \overline{\mathrm{CH}}_{2}-1^{\prime \prime}\right.$ and $\left.\mathrm{C}_{2}-5^{\prime \prime}\right), 1.10(3 \mathrm{H}, \mathrm{s}$, $\left.\left(\mathrm{CH}_{3}\right)\left(\mathrm{CH}_{3}\right) \mathrm{C}-3^{\prime}\right), 0.97\left(3 \mathrm{H}, \mathrm{s},\left(\mathrm{C}_{3}\right) \mathrm{C}-2^{\prime}\right), 0.96\left(3 \mathrm{H}, \mathrm{s},\left(\mathrm{CH}_{3}\right)\right.$ $\left.\left.\left(\mathrm{C}_{3}\right) \mathrm{C}-3^{\prime}\right), 0.88\left(9 \mathrm{H}, \mathrm{s}, \mathrm{SiC}\left(\mathrm{CH}_{3}\right)_{3}\right), 0.46\left(1 \mathrm{H}, \mathrm{t}, J 7.3 \mathrm{~Hz}, \mathrm{C} \underline{H}^{-1}\right)^{\prime}\right)$, $0.03\left(6 \mathrm{H}, \mathrm{s}, \mathrm{Si}\left(\mathrm{CH}_{3}\right)_{2}\right) ;{ }^{13} \mathrm{C}$ NMR $\left(100 \mathrm{MHz}, \mathrm{CDCl}_{3}\right) \delta 134.5$, 131.3, 124.9, 124.4, 60.8, 39.7, 37.9, 34.9, 31.6, 26.8, 26.0 (3C), 25.7, 23.7, 22.6, 22.3, 18.2, 17.7, 17.4, 15.9, 13.8, -5.11, -5.14;
HRMS $\left(\mathrm{CI}^{+}\right)$calcd for $\mathrm{C}_{24} \mathrm{H}_{46} \mathrm{OSi}[\mathrm{M}]^{+}$378.3318, found 378.3309 .

$\left(\left(\left(\left(1 R^{*}, 2 S^{*}\right)-2-((E)-4,8-D i m e t h y l n o n a-3,7-d i e n-1-y l)-2,3,3-t r i-\right.\right.\right.$ methylcyclopropyl)methoxy)methyl)benzene

(18c). $(50 \%$ yield). Colourless oil; $t_{\mathrm{R}}=5.7 \mathrm{~min}$, petroleum ether : ethyl

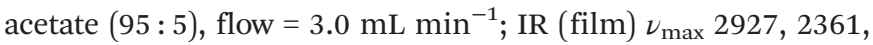
1453, 1377, 1090, 1073, 733, $697 \mathrm{~cm}^{-1}$; ${ }^{1} \mathrm{H}$ NMR (400 MHz, $\left.\mathrm{CDCl}_{3}\right) \delta 7.33-7.24\left(5 \mathrm{H}, \mathrm{m}, \mathrm{H}_{\text {atom }}\right), 5.10\left(2 \mathrm{H}, \mathrm{m}, \mathrm{C} \underline{\mathrm{H}}-3\right.$ " and $\mathrm{C}_{-}-$ 7"), 4.49 (2H, s, $\left.\mathrm{CH}_{2} \mathrm{Ph}\right), 3.50$ (1H, dd, J 10.5, 7.4 Hz, CㅂHOH), $3.45(1 \mathrm{H}, \mathrm{dd}, J 10.5,7.4 \mathrm{~Hz}, \mathrm{CH} \underline{\mathrm{HOH}}), 2.08-1.94\left(4 \mathrm{H}, \mathrm{m}, \mathrm{C}_{2^{-}}\right.$ 2" and $\left.\mathrm{CH}_{2}-6^{\prime \prime}\right), 1.67\left(3 \mathrm{H}, \mathrm{s}, \mathrm{CH}_{3}-9^{\prime \prime}\right), 1.59\left(6 \mathrm{H}, \mathrm{s}, \mathrm{CH}_{3}-1^{\prime \prime \prime}\right.$ and $\left.\left(\mathrm{C}_{3}\right) \mathrm{C}-4^{\prime \prime}\right), 1.48-1.41\left(1 \mathrm{H}, \mathrm{m}, \mathrm{C} \underline{\mathrm{HH}}-1^{\prime \prime}\right), 1.33-1.25$ (3H, m, CH--1" and $\left.\mathrm{CH}_{2}-5^{\prime \prime}\right), 1.13\left(3 \mathrm{H}, \mathrm{s},\left(\mathrm{C}_{3}\right)\left(\mathrm{CH}_{3}\right) \mathrm{C}-3^{\prime}\right), 0.97(3 \mathrm{H}, \mathrm{s}$, $\left.\left(\mathrm{CH}_{3}\right) \mathrm{C}-2^{\prime}\right), 0.95\left(3 \mathrm{H}, \mathrm{s},\left(\mathrm{CH}_{3}\right)\left(\mathrm{CH}_{3}\right) \mathrm{C}-3^{\prime}\right), 0.56(1 \mathrm{H}, \mathrm{t}, J 7.4 \mathrm{~Hz}$, $\left.\mathrm{CH}^{-1}\right) ;{ }^{13} \mathrm{C}$ NMR $\left(100 \mathrm{MHz}, \mathrm{CDCl}_{3}\right) \delta 138.9,134.6,131.3,128.3$ (2C), 127.6 (2C), 127.4, 124.7, 124.4, 72.4, 68.0, 39.7, 38.0, 32.2, $26.7,25.9,25.7,25.6,23.6,22.4,17.7,17.4,15.9,13.9$; HRMS $\left(\mathrm{CI}^{+}\right)$calcd for $\mathrm{C}_{25} \mathrm{H}_{39} \mathrm{O}[\mathrm{M}+\mathrm{H}]^{+}$355.3001, found 355.3006.

$\left(\left(1 R^{*}, 3 S^{*}\right)-1,2,2\right.$-Trimethyl-3-(3-methylbut-3-en-1-yl)cyclopropyl)methanol (19a). (43\% yield). Colourless oil; $t_{\mathrm{R}}=$ $39 \mathrm{~min}$, petroleum ether: ethyl acetate $(85: 15)$, flow $=$

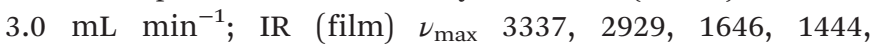
$1378 \mathrm{~cm}^{-1} ;{ }^{1} \mathrm{H}$ NMR (400 MHz, $\left.\mathrm{CDCl}_{3}\right) \delta 4.70(1 \mathrm{H}, \mathrm{br} \mathrm{s}$, CHH-4"), $4.66\left(1 \mathrm{H}\right.$, br s, CHH- $\left.4^{\prime \prime}\right), 3.59(1 \mathrm{H}, \mathrm{d}, J 11.2 \mathrm{~Hz}$, С $\underline{H} \mathrm{HOH}), 3.45(1 \mathrm{H}, \mathrm{d}, J 11.2 \mathrm{~Hz}, \mathrm{CH} \underline{\mathrm{HOH}}), 2.01(2 \mathrm{H}, \mathrm{t}, J 7.8$ $\left.\mathrm{Hz}, \mathrm{CH}_{2}-2^{\prime \prime}\right), 1.71\left(3 \mathrm{H}, \mathrm{s}, \mathrm{CH}_{3}-1^{\prime \prime \prime}\right), 1.44\left(1 \mathrm{H}, \mathrm{m}, \mathrm{CH}-1^{\prime \prime}\right), 1.35$ $\left(1 \mathrm{H}, \mathrm{m}, \mathrm{CH}-\mathbf{H}^{\prime \prime}\right), 1.14\left(3 \mathrm{H}, \mathrm{s},\left(\mathrm{CH}_{3}\right)\left(\mathrm{CH}_{3}\right) \mathrm{C}-2^{\prime}\right), 1.05(3 \mathrm{H}, \mathrm{s}$, $\left.\left(\mathrm{CH}_{3}\right) \mathrm{C}-1^{\prime}\right), 0.97\left(3 \mathrm{H}, \mathrm{s},\left(\mathrm{CH}_{3}\right)\left(\mathrm{CH}_{3}\right) \mathrm{C}-2^{\prime}\right), 0.31(1 \mathrm{H}, \mathrm{t}, J 6.8 \mathrm{~Hz}$, $\left.\mathrm{CH}-3^{\prime}\right) ;{ }^{13} \mathrm{C}$ NMR $\left(100 \mathrm{MHz}, \mathrm{CDCl}_{3}\right) \delta 146.1,109.9,70.6,38.2$, 31.2, 28.0, 23.4, 22.7, 22.4, 21.6, 17.2, 12.2; $\mathrm{HRMS}\left(\mathrm{ESI}^{+}\right)$calcd for $\mathrm{C}_{12} \mathrm{H}_{22} \mathrm{ONa}[\mathrm{M}+\mathrm{Na}]^{+}$205.1568, found 205.1582.

tert-Butyldimethyl $\left(\left(\left(1 R^{*}, 3 S^{*}\right)-1,2,2\right.\right.$-trimethyl-3-(3-methylbut3-en-1-yl)cyclopropyl)methoxy)silane (19b). (29\% yield). Colourless oil; $t_{\mathrm{R}}=10 \mathrm{~min}$, petroleum ether: ethyl acetate

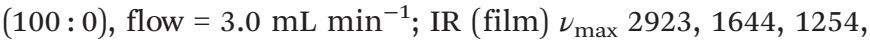
$836 \mathrm{~cm}^{-1}$; ${ }^{1} \mathrm{H}$ NMR $\left(400 \mathrm{MHz}, \mathrm{CDCl}_{3}\right) \delta 4.68(1 \mathrm{H}$, br s,

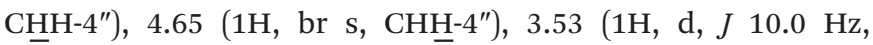
C $\left.\mathrm{Hz}, \mathrm{C}_{2}-2^{\prime \prime}\right), 1.71\left(3 \mathrm{H}, \mathrm{s}, \mathrm{CH}_{3}-^{\prime \prime \prime}\right), 1.37\left(2 \mathrm{H}, \mathrm{m}, \mathrm{C}_{2}-1^{\prime \prime}\right), 1.08$ $\left(3 \mathrm{H}, \mathrm{s},\left(\mathrm{CH}_{3}\right)\left(\mathrm{CH}_{3}\right) \mathrm{C}-2^{\prime}\right), 0.97\left(3 \mathrm{H}, \mathrm{s},\left(\mathrm{CH}_{3}\right) \mathrm{C}-1^{\prime}\right), 0.93(3 \mathrm{H}, \mathrm{s}$, $\left.\left(\mathrm{CH}_{3}\right)\left(\mathrm{CH}_{3}\right) \mathrm{C}-2^{\prime}\right), 0.25\left(1 \mathrm{H}, \mathrm{t}, J 7.0 \mathrm{~Hz}, \mathrm{C}-3^{\prime}\right), 0.02(3 \mathrm{H}, \mathrm{s}$, $\left.\mathrm{SiCH}_{3}\right), 0.00\left(3 \mathrm{H}, \mathrm{s}, \mathrm{SiCH}_{3}\right) ;{ }^{13} \mathrm{C}$ NMR $\left(100 \mathrm{MHz}, \mathrm{CDCl}_{3}\right)$ $\delta$ 146.3, 109.6, 70.0, 38.3, 31.0, 27.5, 25.9 (3C), 23.4, 23.1, 22.5, $21.2,18.3,17.3,12.3,-5.3,-5.4$; HRMS $\left(\mathrm{CI}^{+}\right)$calcd for $\mathrm{C}_{18} \mathrm{H}_{35} \mathrm{OSi}[\mathrm{M}-\mathrm{H}]^{+}$295.2457, found 295.2449.

$\left(\left(\left(\left(1 R^{*}, 3 S^{*}\right)-1,2,2\right.\right.\right.$-Trimethyl-3-(3-methylbut-3-en-1-yl)cyclopropyl)methoxy)methyl)benzene (19c). (50\% yield). Colourless oil; $t_{\mathrm{R}}=10.6 \mathrm{~min}$, petroleum ether : ethyl acetate $(99: 1)$, flow $=$ $3.0 \mathrm{~mL} \mathrm{~min}{ }^{-1}$; IR (film) $\nu_{\max }$ 2932, 2870, 1649, 1495, 736, $698 \mathrm{~cm}^{-1} ;{ }^{1} \mathrm{H}$ NMR $\left(400 \mathrm{MHz}, \mathrm{CDCl}_{3}\right) \delta 7.34-7.26(5 \mathrm{H}, \mathrm{m}$, $\left.\mathrm{H}_{\text {atom }}\right), 4.68\left(1 \mathrm{H}\right.$, br s, $\left.\mathrm{C} \underline{H} \mathrm{H}-4^{\prime \prime}\right), 4.65\left(1 \mathrm{H}\right.$, br s, $\left.\mathrm{CH} \underline{\mathrm{H}}-4^{\prime \prime}\right), 4.49$ $(1 \mathrm{H}, \mathrm{d}, J 12.2 \mathrm{~Hz}, \mathrm{C} \underline{\mathrm{H} P \mathrm{Ph}}), 4.47(1 \mathrm{H}, \mathrm{d}, J 12.2 \mathrm{~Hz}, \mathrm{CH} \underline{\mathrm{HPh}})$, $3.43(1 \mathrm{H}, \mathrm{d}, J 9.8 \mathrm{~Hz}, \mathrm{C} \underline{\mathrm{HOH}}), 3.26(1 \mathrm{H}, \mathrm{d}, J=9.8 \mathrm{~Hz}$, CHㅡㅁㄱ), $2.00\left(2 \mathrm{H}, \mathrm{m}, \mathrm{C}_{2}{ }^{-2}{ }^{\prime \prime}\right), 1.71\left(3 \mathrm{H}, \mathrm{s}, \mathrm{C}_{3}-1^{\prime \prime \prime}\right), 1.39(2 \mathrm{H}$, $\left.\mathrm{m}, \mathrm{C}_{2}-1^{\prime \prime}\right), 1.09\left(3 \mathrm{H}, \mathrm{s},\left(\mathrm{CH}_{3}\right)\left(\mathrm{CH}_{3}\right) \mathrm{C}-2^{\prime}\right), 1.05\left(3 \mathrm{H}, \mathrm{s},\left(\mathrm{CH}_{3}\right)\right.$ C-1'), $0.97\left(3 \mathrm{H}, \mathrm{s},\left(\mathrm{CH}_{3}\right)\left(\mathrm{CH}_{3}\right) \mathrm{C}-2^{\prime}\right), 0.26\left(1 \mathrm{H}, \mathrm{t}, J 7.2 \mathrm{~Hz}, \mathrm{CH}_{-} 3^{\prime}\right)$; 
${ }^{13} \mathrm{C}$ NMR $\left(100 \mathrm{MHz}, \mathrm{CDCl}_{3}\right) \delta$ 146.1, 139.0, $128.2(2 \mathrm{C}), 127.6$ (2C), 127.3, 109.7, 77.6, 72.6, 38.2, 31.2, 25.7, 23.6, 22.9, 22.5, 21.4, 17.0, 12.7; HRMS $\left(\mathrm{APCI}^{+}\right)$calcd for $\mathrm{C}_{19} \mathrm{H}_{29} \mathrm{O}[\mathrm{M}+\mathrm{H}]^{+}$ 273.2218 , found 273.2230 .

\section{Acknowledgements}

This research was supported by a grant from the Junta de Andalucia (P07-FQM-02925) and in part from MINECO-FEDER (AGL2012-39798-C02-01). The use of NMR and mass spectrometry facilities at the Servicios Centrales de Investigación Científica y Tecnológica (SC-ICYT) of the University of Cádiz is acknowledged.

\section{Notes and references}

1 (a) R. Csuk, M. J. Schabel and Y. von Schoolz, Tetrahedron: Asymmetry, 1996, 7, 3505-3512; (b) H. W. Liu and C. H. Walsh, in The Chemistry of cyclopropyl group, ed. Z. Rappoport, John Wiley, New York, 1997, p. 959; (c) J. S. Kumar, S. Roy and A. Datta, Bioorg. Med. Chem. Lett., 1999, 9, 513-514; (d) X. Zhang, K. Hodgetts, S. Rachwal, H. Zhao, J. W. F. Wasley, K. Gravenm, R. Bordbeck, A. Kieltyka, D. Hoffman, M. D. Bacolod, B. Girad, J. Tran and A. Thurkauf, J. Med. Chem., 2000, 43, 3923-3932.

2 C. J. Suckling, Angew. Chem., Int. Ed., 1988, 27, 537-552.

3 M. J. Duran-Peña, J. M. Botubol Ares, I. G. Collado and R. Hernández-Galán, Nat. Prod. Rep., 2014, 31, 940-952.

4 H. M. L. Davies, Tetrahedron, 1993, 49, 5203-5223.

5 T. Hudlicky and J. W. Reed, in Comprehensive Organic Synthesis, ed. B. M. Trost and I. Fleming, Pergamon Press, Oxford, 1991, vol. 5, 899.

6 D. C. Nonhebel, Chem. Soc. Rev., 1993, 22, 347-359.

7 (a) R. D. Little and J. R. Dawson, Tetrahedron Lett., 1980, 21, 2609-2612; (b) A. B. Charette, in Compr. Org. Synth, Elsevier B.V., 2nd edn, 2014, vol. 4, pp. 1054-1080; (c) X. Xin, Q. Zhang, Y. Liang, R. Zhang and D. Dong, Org. Biomol. Chem., 2014, 12, 2427-2435.

8 (a) M. P. Doyle and D. C. Forbes, Chem. Rev., 1998, 98, 911936; (b) Z. Zhang and J. Wang, Tetrahedron, 2008, 64, 65776605.

9 (a) R. P. Panne, A. DeAngelis and J. M. Fox, Org. Lett., 2008, 10, 2987-2989; (b) R. G. Maas, Chem. Soc. Rev., 2004, 33, 183-190; (c) A. L. Liu and J. Zhang, Chem. Soc. Rev., 2016, 45, 506-516.

10 (a) C. Bruneau, Angew. Chem., Int. Ed., 2005, 44, 2328-2334; (b) D. Qian and J. Zhang, Chem. Soc. Rev., 2015, 44, 677698.

11 (a) O. G. Kulinkovich, Chem. Rev., 2003, 103, 2597-2632; (b) J. K. Cha and O. G. Kulinkovich, Org. React., 2012, 77, 1159; (c) I. Haym and M. A. Brimble, Org. Biomol. Chem., 2012, 10, 7649-7665.
12 (a) W. Doering and A. K. Hoffmann, J. Am. Chem. Soc., 1954, 76, 6162; (b) G. L. Closs and R. A. Moss, J. Am. Chem. Soc., 1964, 86, 4042-4053.

13 (a) H. Lebel, J.-F. Marcoux, C. Molinaro and A. B. Charette, Chem. Rev., 2003, 103, 977-1050; (b) M.-N. Roy, V. N. G. Lindsay and A. B. Charette, in Stereoselective Synthesis: Reactions of Carbon-Carbon Double Bonds (Science of Synthesis Series), ed. J. G. de Vries, Thieme, Stuttgart, 2011, vol. 1, ch. 1.14, pp. 731-817.

14 (a) H. Pellissier, Tetrahedron, 2008, 64, 7041-7095; (b) I. Nicolas, P. Le Maux and G. Simonneaux, Coord. Chem. Rev., 2008, 252, 727-735; (c) G. Bartoli, G. Bencivenni and R. Dalpozzo, Synthesis, 2014, 46, 979-1029.

15 A. Moyano and R. Rios, Chem. Rev., 2011, 111, 4703-4832.

16 B. Rickborn and J. H. Chan, J. Org. Chem., 1967, 32, 35763580 .

17 H. E. Simmons and R. D. Smith, J. Am. Chem. Soc., 1958, 80, 5323-5324.

18 (a) H. Kim, Acc. Chem. Res., 2012, 45, 1533-1547; (b) R. G. Cornwall, O. A. Wong, H. Du, T. A. Ramirez and Y. Shi, Org. Biomol. Chem., 2012, 10, 5498-5513; (c) K. Fujii, K. Shiine, T. Misaki and T. Sugimura, Appl. Organomet. Chem., 2013, 27, 69-72; (d) L. P. B. Beaulieu, J. F. Schneider and A. B. Charette, J. Am. Chem. Soc., 2013, 135, 7819-7822; (e) Y. Ishizuka, H. Fujimori, T. Noguchi, M. Kawasaki, M. Kishida, T. Nagai, N. Imai and M. Kirihara, Chem. Lett., 2013, 42, 1311-1313; (f) M. Rachwalski, S. Kaczmarczyk, S. Lesniak and P. Kielbasinski, ChemCatChem, 2014, 6, 873-875; $(g)$ E. Levesque, S. R. Goudreau and A. B. Charette, Org. Lett., 2014, 16, 1490-1493.

19 (a) J.-F. Fournier, S. Mathieu and A. B. Charette, J. Am. Chem. Soc., 2005, 127, 13140-13141; (b) H. Y. Kim, L. Salvi, P. J. Carroll and P. J. Walsh, J. Am. Chem. Soc., 2009, 131, 954-962; (c) C. Navuluri and A. B. Charette, Org. Lett., 2015, 17, 4288-4291.

20 L.-P. B. Beaulieu, J. F. Schneider and A. B. Charette, J. Am. Chem. Soc., 2013, 135, 7819-7822.

21 (a) G. Boche and J. C. W. Lohrenz, Chem. Rev., 2001, 101, 697-756; (b) M. Braun, Angew. Chem., Int. Ed., 1998, 37, 430-451; (c) M. Braun, in The Chemistry of Organolithium Compounds, ed. Z. Rappoport and I. Marek, John Wiley \& Sons, Inc., New York, 2004, vol. 2, ch. 13, pp. 829-900; (d) V. Capriati and S. Florio, Chem. - Eur. J., 2010, 16, 41524162; (e) V. Capriati, Contemporary Carbene Chemistry, in Modern Lithium Carbenoid Chemistry, ed. R. A. Moss and M. P. Doyle, Wiley, New York, 2014, ch. 11, pp. 327-362.

22 (a) V. Capriati, S. Florio, F. M. Perna, A. Salomone, A. Abbotto, M. Amedjkouh and S. O. Nilsson Lill, Chem. Eur. J., 2009, 15, 7958-7979; (b) A. Salomone, F. M. Perna, A. Falcicchio, S. O. Nilsson Lill, A. Moliterni, R. Michel, S. Florio, D. Stalke and V. Capriati, Chem. Sci., 2014, 5, 528-538.

23 Chloromethyllithium is obtained by treatment of bromochloromethane with $n$-BuLi, and not from chloromethane; see: G. Koebrich and R. H. Fischer, Tetrahedron, 1968, 24, 4343-4346. 
24 Dichloromethyllithium from dichloromethane: (a) G. Köbrich, K. Flory and W. Drischel, Angew. Chem., Int. Ed. Engl., 1964, 3, 513-513; (b) D. F. Hoeg, D. I. Lusk and A. L. Crumbliss, J. Am. Chem. Soc., 1965, 87, 4147-4155; (c) G. Koebrich and H. R. Merkle, Chem. Ber., 1966, 99, 1782-1792; (d) J. Villieras, P. Perriot and J. F. Normant, Bull. Soc. Chim. Fr., 1977, 765-768; (e) J. Villieras, P. Perriot and J. F. Normant, Synthesis, 1979, 502-504; (f) K. Sato, K. Suzuki, M. Ueda, M. Katayama and Y. Kajihara, Chem. Lett., 1991, 1469-1472.

25 U. Schöllkopf, Houben-Weyl, Methoden der Organischen Chemie, 13/1, ed. E. Müller, Thieme, Stuttgart, 1970, p. 134.

26 (a) A. H. Hoveyda, D. A. Evans and G. C. Fu, Chem. Rev., 1993, 93, 1307-1370, and references therein; (b) A. B. Charette and A. Beauchemin, Org. React., 2001, 58, 1-415, and references therein.

27 M. J. Durán-Peña, J. M. Botubol Ares, J. R. Hanson, I. G. Collado and R. Hernández-Galán, Nat. Prod. Rep., 2015, 32, 1236-1248.

28 D. Arlt, M. Jautelat and R. Lantzsch, Angew. Chem., Int. Ed. Engl., 1981, 20, 703-722.

29 M. G. Edwards, R. J. Paxton, D. S. Pugh, A. C. Whitwood and R. J. K. Taylor, Synthesis, 2008, 3279-3288.

30 A. B. Charette and N. Wilb, Synlett, 2002, 176-178, and references therein.

31 P. Fischer and G. Schaefer, Angew. Chem., Int. Ed. Engl., 1981, 20, 863-864.

32 M. G. B. Drew, L. M. Harwood, A. J. Macías-Sánchez, R. Scott, R. M. Thomas and D. Uguen, Angew. Chem., Int. Ed., 2001, 40, 2311-2313.

33 H. E. Simmons and R. D. Smith, J. Am. Chem. Soc., 1959, 81, 4256-4264.

34 D. Cheng, D. Huang and Y. Shi, Org. Biomol. Chem., 2013, 11, 5588-5591.

35 A. B. Charette and A. Beauchemin, J. Organomet. Chem., 2001, 617-618, 702-708.

36 G. A. Molander, J. B. Etter and P. W. Zinke, J. Am. Chem. Soc., 1987, 109, 453-463.

37 G. A. Molander and L. S. Harring, J. Org. Chem., 1989, 54, 3525-3532.

38 G. Brunner, L. Eberhard, J. Oetiker and F. Schröder, J. Org. Chem., 2008, 73, 7543-7554.

39 M. J. Durán-Peña, J. M. Botubol-Ares, J. R. Hanson, R. Hernández-Galán and I. G. Collado, Org. Biomol. Chem., 2015, 13, 6325-6332.

40 K. Maruoka, Y. Fukutani and H. Yamamoto, J. Org. Chem., 1985, 50, 4412-4414.

41 G. Brunner, S. Elmer and F. Schröder, Eur. J. Org. Chem., 2011, 4623-4633.
42 G. L. Closs and G. M. Schwartz, J. Am. Chem. Soc., 1960, 82, 5729-5731.

43 R. Barlet and M. Vincens, Tetrahedron, 1977, 33, 12911302.

44 R. Barlet, B. Baharmast and M. Vidal, Tetrahedron Lett., 1990, 31, 3553-3554.

45 G. Wittig and F. Wingler, Chem. Ber., 1964, 97, 2146-2164.

46 H. C. Stiasny and R. W. Hoffmann, Chem. - Eur. J., 1996, 1, 619-624.

47 F. Bernardi, A. Bottoni and G. P. Miscione, J. Am. Chem. Soc., 1997, 119, 12300-12305.

48 A. Hirai, M. Nakamura and E. Nakamura, Chem. Lett., 1998, 927-928.

49 M. Nakamura, A. Hirai and E. Nakamura, J. Am. Chem. Soc., 2003, 125, 2341-2350.

50 H. Hoberg, Liebigs Ann. Chem., 1962, 656, 1-14.

51 Z.-H. Li, Z. Ke, C. Zhao, Z.-Y. Geng, Y.-C. Wang and D. L. Philips, Organometallics, 2006, 25, 3735-3742.

52 U. Burger and R. Huisgen, Tetrahedron Lett., 1970, 11, 3049-3051.

53 T. Kottke and D. Stalke, Angew. Chem., Int. Ed. Engl., 1993, 32, 580-582.

54 Z. Ke, Y. Zhou, H. Gao, C. Zhao and D. L. Phillips, Chem. Eur. J., 2007, 13, 6724-6731.

55 L. M. Pratt, P. T. T. Tran, N. V. Nguyen and B. Ramachandran, Bull. Chem. Soc. Jpn., 2009, 82, 11071125.

56 B. Ramachandran, P. Kharidehal, L. M. Pratt, S. Voit, F. N. Okeke and M. Ewan, J. Phys. Chem. A, 2010, 114, 8423-8433.

57 H. Asao, H. Sakauchi, S. Kuwahara and H. Kiyota, Tetrahedron: Asymmetry, 2007, 18, 537-541.

58 H. Sakauchi, H. Asao, T. Hasaba, S. Kuwahara and H. Kiyota, Chem. Biodiversity, 2006, 3, 544-552.

59 T. K. Baryshnikova, M. E. Niyazymbetov, V. S. Bogdanov and V. A. Petrosyan, Bull. Acad. Sci. USSR Div. Chem. Sci., 1988, 37, 2093-2095; see discussion of spectroscopic observations for compound $\mathbf{1 0}$ at ESI. $\dagger$

60 Described as an acetyl derivative, see ref. 61 see discussion of spectroscopic observations for compound $\mathbf{1 1}$ at ESI. $\dagger$

61 G. V. Kryshtal, G. M. Zhdankina and S. G. Zlotin, Eur. J. Org. Chem., 2008, 1777-1782.

62 J. M. Botubol-Ares, M. J. Durán-Peña, A. J. Macías-Sánchez, J. R. Hanson, I. G. Collado and R. Hernández-Galán, Org. Biomol. Chem., 2014, 12, 5304-5310.

63 D. E. Cane, H. J. Ha, D. B. McIlwaine and K. O. Pascoe, Tetrahedron Lett., 1990, 31, 7553-7554.

64 F.-L. Wu, B. P. Ross and R. P. McGeary, Eur. J. Org. Chem., 2010, 1989-1998. 